\title{
CecropinXJ inhibits the proliferation of human gastric cancer BGC823 cells and induces cell death in vitro and in vivo
}

\author{
YAN-LING WU, LI-JIE XIA, JIN-YAO LI and FU-CHUN ZHANG \\ Xinjiang Key Laboratory of Biological Resources and Genetic Engineering, \\ College of Life Science and Technology, Xinjiang University, Tianshan, Urumqi 830046, P.R. China
}

Received December 19, 2014; Accepted February 5, 2015

DOI: 10.3892/ijo.2015.2933

\begin{abstract}
We have shown that an antimicrobial peptide (AMP) cecropinXJ isolated from the larvae of Bombyx mori selectively inhibits the proliferation of cancer cells. However, the mechanism remains to be determined. In the present study, we examined the antitumor activity of cecropinXJ against human gastric cancer BGC823 cells and explored the mechanism. The results showed that cecropinXJ inhibited the growth of gastric cancer BGC823 cells in vitro and in vivo. MTT and colony formation assays indicated that cecropinXJ suppressed cell proliferation and reduced colony formation of BGC823 cells in a dose- and time-dependent manner, but without inhibitory effect on normal gastric epithelia GES-1 cells. S-phase arrest in BGC823 cells was observed after treatment with cecropinXJ. Annexin V/PI staining suggested that cecropinXJ induced both early and late phases of apoptosis through activation of mitochondrial-mediated caspase pathway, upregulation of Bax expression and downregulation of Bcl-2 expression. Additionally, cecropin XJ treatment increased reactive oxygen species (ROS) production, disrupted the mitochondrial membrane potential $\left(\Delta \psi_{\mathrm{m}}\right)$ and led to release of cytochrome c. Importantly, in vivo study showed that cecropinXJ significantly prevented the growth of xenograft tumor in the BGC823-bearing mice, possibly mediated by the induction of apoptosis and inhibition of angiogenesis. These results suggest that cecropinXJ may be a promising therapeutic candidate for the treatment of gastric cancer.
\end{abstract}

Correspondence to: Professor Fu-Chun Zhang, Xinjiang Key Laboratory of Biological Resources and Genetic Engineering, College of Life Science and Technology, Xinjiang University, 666 Shengli Road, Tianshan, Urumqi 830046, P.R. China

E-mail: zfcxju@xju.edu.cn

Abbreviations: AMPs, antimicrobial peptides; ROS, reactive oxygen species; MAPK, mitogen-activated protein kinase; NF- $\mathrm{KB}$, nuclear factor-kappa B; PI3K/Akt, phosphoinositide 3-kinase/protein kinase B

Key words: cecropinXJ, gastric cancer, antitumor, proliferation, apoptosis, mitochondrial-mediated pathway, angiogenesis

\section{Introduction}

Gastric cancer is one of the most common malignant tumors, $>70 \%$ of new cases and deaths occur in developing countries each year (1). In China, the incidence and mortality rate of gastric cancer are increasing. Although there are distinct discrepancies in diagnosis, prognosis, and treatment efficacy for gastric cancer patients, the 5-year survival rate of gastric cancer is generally $<20 \%$ (2). At present, the management of gastric cancer includes surgery, radiotherapy, conventional chemotherapy, molecular targeted therapy and biological therapy, but these methods have not reached expected clinical efficacy, which mainly focus on mass cell killing without high specificity and often causes severe side-effects and toxicities. Moreover, recurrences and metastasis frequently occur in the majority of patients (2). Hence, it is urgent to explore safe and effective therapeutic agents for gastric cancer to improve the survival rate and quality of life.

Antimicrobial peptides (AMPs) are evolutionarilyconserved components of the innate immune system (3), which exert their activities against a broad range of microbial pathogens. Compared to conventional treatments, AMPs have many advantages, such as specific cytotoxicity for cancer cells, ability to bypass the multidrug-resistance mechanism, and additive effects in combination therapy (4), suggesting that AMPs has potential as a novel antitumor agent for the treatment of cancer.

AMPs can directly kill cancer cells by a cell membranelytic effect (5), or trigger apoptosis in cancer cells via the Fas death-receptor-induced extrinsic pathway (6) and the mitochondria-apoptosome-mediated apoptotic intrinsic pathway (7). AMPs with cationic and amphipathic amino acid composition can penetrate anionic cell membrane and subsequently bind to mitochondrial membrane, which destroy membrane structure, increase the level of reactive oxygen species (ROS) and decrease mitochondrial membrane potential $\left(\Delta \psi_{\mathrm{m}}\right)(8)$. Mitochondrial dysfunction elicits the release of cytochrome $c$ from mitochondria to cytosol, which activates the caspase-cascade system and induces cell apoptosis (9). It has been reported that AMPs inhibited the growth or proliferation of cancer cells through regulation of numerous proteins and pathways, including the caspase family and the Bcl-2 family $(10,11)$, the mitogen-activated protein kinase (MAPK) family (12), the nuclear factor-kappa B (NF-кB) (13), 
phosphoinositide 3-kinase (PI3K)/protein kinase B (Akt) signal transduction pathways $(14,15)$ and ER stress-mediated apoptosis pathway $(16,17)$. Furthermore, certain AMPs are potent inhibitors of blood vessel development (angiogenesis) that is associated with tumor progression (18).

We isolated a 37-AA cationic antimicrobial peptide with specific amphipathic $\alpha$-helices (named as cecropinXJ) from the larvae of Bombyx mori (19), which has a broad effect spectrum against bacteria (20). Our previous studies have shown that cecropinXJ can inhibit the proliferation of human gastric cancer in vitro such as AGS cells (21), but have no hemolytic activity against human erythrocytes and no toxicity to normal mammalian cells $(22,23)$. Due to difficulty of AGS cells to form a solid tumor in vivo, we investigated the cytotoxicity and the mechanism of cecropinXJ against the human gastric cancer BGC823 cells in the present study. Our results showed that cecropinXJ suppressed the proliferation and induced apoptosis of BGC823 cells in vitro and in vivo through mitochondrialmediated apoptosis pathways and inhibition of angiogenesis, which could provide experimental evidence for the potential application of cecropinXJ as a new antitumor candidate for treatment of gastric cancer.

\section{Materials and methods}

Preparation of antimicrobial peptide cecropinXJ. CecropinXJ of B. mori was prepared through the Saccharomyces cerevisiae eukaryotic expression system and purified with Ni-NTA agarose column as reported (23). The concentration of purified recombinant cecropinXJ protein was detected by a Bradford protein assay kit (KeyGen Biotech, Nanjing, China). The amino acid sequence is WKIFKKIEKMGRNIRDGIVKAGPAIEVLGSAKAIGK. Before use, the peptide was dissolved in Dulbecco's modified Eagle's medium (DMEM; Hyclone, Logan, UT, USA) at a concentration of $1 \mathrm{mg} / \mathrm{ml}$ and sterilized by filtration through a 0.2 -mm filter.

Cell culture. The human gastric cancer BGC823 cells and normal gastric epithelial GES-1 cells were kindly provided by Professor Youyong Lv (Beijing Cancer Hospital, Beijing, China). Cells were cultured in DMEM medium, supplemented with $10 \%$ fetal bovine serum (FBS; Gibco-BRL, Grand Island, NY, USA), $100 \mu \mathrm{g} / \mathrm{ml}$ streptomycin and $100 \mathrm{U} / \mathrm{ml}$ penicillin (Beijing Solarbio, Beijing, China) in a humidified atmosphere of $5 \% \mathrm{CO}_{2}$ at $37^{\circ} \mathrm{C}$.

Cell viability assay. To evaluate the effects of cecropinXJ on the proliferation of BGC823 cells and GES- 1 cells, cell viability was measured by 3-[4,5-dimethylthiazol-2-yl]2,5-diphenyltetrazolium bromide (MTT) assay (Sigma, St. Louis, MO, USA). The BGC823 cells and GES- 1 cells in the logarithmic phase of growth were collected and seeded in 96-well plates at a density of $5 \times 10^{3}$ cells/well and cultured overnight. After 24 h, BGC823 cells and GES-1 cells were treated with or without cecropinXJ at different concentrations $(0-1,000 \mu \mathrm{g} / \mathrm{ml})$ for $24 \mathrm{~h}$, respectively. To examine the timedependent effect of cecropinXJ, BGC823 cells and GES-1 cells were treated by different concentrations of cecropinXJ $(20,50$, 80 and $100 \mu \mathrm{g} / \mathrm{ml}$ ) for $24,48,72,96$ and $120 \mathrm{~h}$ and $10 \mu \mathrm{g} / \mathrm{ml}$ doxorubicin (Dox) served as a positive control. To investigate the effects of caspases on cell viability, cells were pre-treated with $100 \mu \mathrm{M}$ PAN-caspase inhibitor (Ac-VAD-fmk), caspase-3 inhibitor (Ac-DEVD-fmk), caspase-8 inhibitor (Ac-IETD-fmk) and caspase-9 inhibitor (Ac-LEHD-fmk) (Enzo Life Sciences, Lausen, Switzerland) for $60 \mathrm{~min}$, then treated with different concentrations of cecropinXJ $(0,20,50,80$ and $100 \mu \mathrm{g} / \mathrm{ml})$ for $24 \mathrm{~h}$. After treatment, the culture medium was removed and $100 \mu \mathrm{l}$ MTT solution $(5 \mathrm{mg} / \mathrm{ml})$ was added into each well, then incubated at $37^{\circ} \mathrm{C}$ for $4 \mathrm{~h}$. After $4 \mathrm{~h}, 150 \mu \mathrm{l}$ of dimethyl sulfoxide (DMSO; Beijing Solarbio) was added into each well and incubated at $37^{\circ} \mathrm{C}$ for $10 \mathrm{~min}$. Absorbance was measured at $\mathrm{OD}_{540 / 655 \mathrm{~nm}}$ using a 96-well microplate reader (Bio-Rad Laboratories, Hercules, CA, USA). Cell viability $(\%)=$ $\left[\left(\mathrm{OD}_{\text {treated }}-\mathrm{OD}_{\text {blank }}\right) /\left(\mathrm{OD}_{\text {non-treated }}-\mathrm{OD}_{\text {blank }}\right)\right] \times 100 \%$.

Colony formation assay. One thousand BGC823 cells were resuspended in $4.4 \mathrm{ml}$ mixture of $0.5 \%$ agar solution containing cell culture medium (2X DMEM and 20\% FBS) at a final concentration of 20,50,80 and $100 \mu \mathrm{g} / \mathrm{ml}$ cecropinXJ and layered on the top of $0.7 \%$ agar layer in $60-\mathrm{mm}$ petri-dish (Corning). The mixtures without cecropinXJ or with $10 \mu \mathrm{g} /$ $\mathrm{ml}$ Dox served as negative and positive controls, respectively. Dishes were incubated for three weeks at $37^{\circ} \mathrm{C}$ in a humidified atmosphere of $5 \% \mathrm{CO}_{2}$. Cell colonies were observed by light microscopy (Leica Microsystems, Wetzlar, Germany) and visualized by the treatment of $0.5 \mathrm{ml} \mathrm{p}$-iodonitrotetrazolium violet (Sigma) for $16 \mathrm{~h}$, then photographed and the number of cell clonies was counted. Colonies $(\%)=$ the colony number of treatment group/the colony number of control group x $100 \%$.

LDH detection. BGC 823 and GES-1 cells at $4 \times 10^{5}$ cells/well were inoculated into 24-well plates and treated with $0,20,50$, 80 and $100 \mu \mathrm{g} / \mathrm{ml}$ of cecropinXJ for 24 or $48 \mathrm{~h}$. Medium was collected and the ratio of LDH release was detected according to the manufacturer's instructions.

Cell cycle analysis of cecropinXJ on BGC823 cells by flow cytometry. BGC 823 cells at $5 \times 10^{6}$ cells $/ \mathrm{ml}$ were inoculated into $100-\mathrm{mm}$ dishes and incubated at $37^{\circ} \mathrm{C}$ for $24 \mathrm{~h}$. After the medium was removed, fresh medium with different concentrations of cecropinXJ was added and cultured. Medium without cecropinXJ was served as the control. After culture for 24 or $48 \mathrm{~h}$, the cells were collected and washed with cold phosphatebuffered saline (PBS, pH 7.4) and fixed with $75 \%$ ethanol overnight at $-20^{\circ} \mathrm{C}$. After washing, DNA staining solution (Multisciences, Hangzhou, China) was added and incubated at $37^{\circ} \mathrm{C}$ in darkness for $30 \mathrm{~min}$. The samples were analyzed with a flow cytometry (BD Biosciences, San Jose, CA, USA).

Apoptosis rate determined by flow cytometry. BGC 823 cells at $5 \times 10^{5}$ cells $/ \mathrm{ml}$ were inoculated into $60-\mathrm{mm}$ dishes and incubated at $37^{\circ} \mathrm{C}$ for $24 \mathrm{~h}$. After the medium was removed, $2.0 \mathrm{ml}$ of DMEM medium with the final concentrations of cecropinXJ at 20,50, 80 and $100 \mu \mathrm{g} / \mathrm{ml}$ was added to each dish. No cecropinXJ served as the control. After cultured for 24 or $48 \mathrm{~h}$, cells were collected after digestion with $0.25 \%$ trypsin, washed with PBS two times, and suspended in $400 \mu \mathrm{l}$ binding buffer. Cell suspensions were stained with $5 \mu \mathrm{l}$ of Annexin V-FITC and $10 \mu \mathrm{l}$ of propidium iodide (PI) (BestBio Biotechnologies, Shanghai, China) according to the manufac- 
turer's instructions, and the samples were analyzed with a flow cytometry.

Morphological observation by Hoechst 33258 staining and transmission electron microscopy. The BGC823 cells were treated with different concentrations of cecropinXJ for $24 \mathrm{~h}$. For Hoechst 33258 staining, cells were washed with PBS and fixed with $95 \%$ ethanol at $4^{\circ} \mathrm{C}$ for $15 \mathrm{~min}$. After washing with PBS, cells were stained with $0.5 \mu \mathrm{g} / \mathrm{ml}$ Hoechst 33258 (Sigma) for $10 \mathrm{~min}$ at $4^{\circ} \mathrm{C}$ in the dark. Samples were observed under a fluorescence microscope (Leica Microsystems). For transmission electron microscope, cells were fixed with $2.5 \%$ glutaraldehyde in $0.1 \mathrm{M}$ PBS at $4^{\circ} \mathrm{C}$ overnight, and fixed with $1 \%$ osmium tetraoxide after washing with PBS. The cells were then dehydrated using graded alcohol and embedded in araldite. Ultrathin sections were stained with uranyl acetate and lead citrate and examined with a Philips CM10 transmission electron microscope.

Detection of reactive oxygen species (ROS) and mitochondrial membrane potential $\left(\Delta \psi_{m}\right)$. ROS were detected by non-fluorescent 2,7-dichlorodihydrofluorescein $\left(\mathrm{H}_{2} \mathrm{DCF}-\mathrm{DA}\right)$ (Sigma) (a fluorogenic freely permeable tracer), which is specific for ROS assessment. Changes in the mitochondrial membrane potential $\left(\Delta \psi_{\mathrm{m}}\right)$ were measured using a lipophilic cationic dye 3,3-dihexyloxacarbocyanine iodide $\left[\mathrm{DiOC}_{6}(3)\right]$ (Sigma). Briefly, BGC823 cells $\left(2 \times 10^{6}\right.$ cells $\left./ \mathrm{ml}\right)$ were treated with different concentrations of cecropinXJ for $24 \mathrm{~h}$ or treated with $100 \mu \mathrm{g} / \mathrm{ml}$ cecropinXJ for different times in 100-mm dishes. After treatment, cells were incubated with $10 \mu \mathrm{M} \mathrm{H}_{2} \mathrm{DCF}-\mathrm{DA}$ for $30 \mathrm{~min}$ or $40 \mathrm{nM} \mathrm{DiOC}_{6}(3)$ for $15 \mathrm{~min}$ at $37^{\circ} \mathrm{C}$, and washed with PBS. The samples were analyzed by flow cytometry.

Quantitative real-time reverse-transcription PCR ( $q R T-P C R)$. Gene expression was analyzed by qRT-PCR. Total RNA was extracted from BGC823 cells and tumors using TRIzol reagent (Invitrogen, Carlsbad, CA, USA) according to the manufacturer's protocol. cDNA was synthesized from total RNA by M-MLV reverse transcriptase according to the instruction. Gene expression was detected by SYBR ${ }^{\circledR}$ Premix Ex Taq ${ }^{\mathrm{TM}}$ II (Tli RNaseH Plus) (Takara, Tokyo, Japan) using the $7500^{\mathrm{TM}}$ Real-time system (Applied Biosystems, Waltham, MA, USA). $G A P D H$ was used as the reference gene. The primers are shown in Table I. For qRT-PCR, each reaction was run in triplicate and contained the following: $12.5 \mu \mathrm{l}$ of Premix Ex Taq ${ }^{\mathrm{TM}} \mathrm{II}$, $2 \mu \mathrm{l}$ of forward primer and reverse primer $(2.5 \mu \mathrm{M}), 0.5 \mu \mathrm{l}$ of ROX Reference Dye II (50X) and 100 ng cDNA template in a final reaction volume of $25 \mu \mathrm{l}$. After a pre-incubation step at $95^{\circ} \mathrm{C}$ for $30 \mathrm{sec}$ to activate DNA polymerase, 40 cycles of PCR were done following the conditions: $95^{\circ} \mathrm{C}$ for $30 \mathrm{sec}, 56^{\circ} \mathrm{C}$ for $30 \mathrm{sec}$ and $72^{\circ} \mathrm{C}$ for $45 \mathrm{sec}$. The expression levels were quantified using the cycle threshold value $(\mathrm{Ct})$. Data were normalized to GAPDH and the relative expression levels of the genes were calculated using the $2^{-\Delta \Delta C t}$ method.

Western blot analysis. BGC823 cells were treated with cecropinXJ $(0,20,50,80$ and $100 \mu \mathrm{g} / \mathrm{ml})$ for $24 \mathrm{~h}$ and washing with ice-cold PBS twice, cells were collected and lysed using $100 \mu 1$ CytoBuster $^{\mathrm{TM}}$ protein extraction reagent (Novage, Madison, WI, USA) on ice for $15 \mathrm{~min}$. After centrifugation at
Table I. Primers were designed for qRT-PCR.

\begin{tabular}{|c|c|c|}
\hline Primers & Sequences $\left(5^{\prime}-3{ }^{\prime}\right)$ & $\begin{array}{l}\text { Length } \\
\text { (bp) }\end{array}$ \\
\hline Caspase-3 & $\begin{array}{l}\text { F: AGACATACTCCTTCCATCA A } \\
\text { R: TCATAGCACAGCATCACT }\end{array}$ & 182 \\
\hline Caspase- 8 & $\begin{array}{l}\text { F: CAGAAGAAGTGAGCAGAT } \\
\text { R: GAGTCCGAGATTGTCATT }\end{array}$ & 262 \\
\hline Caspase-9 & $\begin{array}{l}\text { F: GCCTGGAGTCTTAGTTG } \\
\text { R: CTGCTTGCCTGTTAGTT }\end{array}$ & 313 \\
\hline Bcl-2 & $\begin{array}{l}\text { F: GAACTGGGGGAGGATTGTGG } \\
\text { R: GGATCCAGGTGTGCAGGTGC }\end{array}$ & 143 \\
\hline Bax & $\begin{array}{l}\text { F: GATGATTGCCGCCGTGGAC } \\
\text { R: GGGTGAGGAGGCTTGAGGAG }\end{array}$ & 267 \\
\hline Cytochrome $c$ & $\begin{array}{l}\text { F: TGGATACTCTTACACAGCCG } \\
\text { R: AAGTCTGCCCTTTCTTCCTT }\end{array}$ & 150 \\
\hline CD31 & $\begin{array}{l}\text { F: GAGTCCTGCTGACCCTTCTG } \\
\text { R: ATCTGGTGCTGAGGCTTGAC }\end{array}$ & 188 \\
\hline CD34 & $\begin{array}{l}\text { F: TCAGGCATCAGAGAAGTG } \\
\text { R: CAAGACCAGCAGTAGACA }\end{array}$ & 210 \\
\hline bFGF & $\begin{array}{l}\text { F: AGCGACCCTCACATCAAG } \\
\text { R: AAGAAACACTCATCCGTAACAC }\end{array}$ & 143 \\
\hline VEGF & $\begin{array}{l}\text { F: AACTTTCTGCTGTCTTGGG } \\
\text { R: ACTTCGTGATGATTCTGCC }\end{array}$ & 116 \\
\hline VWF & $\begin{array}{l}\text { F: CGCATCCAGCATACAGTGAC } \\
\text { R: GAGGGGGTAAGGAAGTCGTC }\end{array}$ & 176 \\
\hline GAPDH & $\begin{array}{l}\text { F: ACACCCACTCCTCCACCTTT } \\
\text { R: ACCCTGTTGCTGTAGCCAA }\end{array}$ & 106 \\
\hline
\end{tabular}

F, forward; R, reverse.

$14,000 \mathrm{rpm} 4^{\circ} \mathrm{C}$ for $10 \mathrm{~min}$, the protein concentration in supernatant was determined by the bicinchoninic acid (BCA) assay kit. Proteins ( $40 \mu \mathrm{g} /$ lane) were separated by $12 \%$ SDS-PAGE and transferred onto a nitrocellulose membranes (Millipore, Billerica, MA, USA). After washing with TBS-T buffer $(20 \mathrm{mM}$ Tris- $\mathrm{HCl}, 150 \mathrm{mM} \mathrm{NaCl}, 0.05 \%$ Tween-20), membrane was blocked with $5 \%$ skim milk at room temperature for $1 \mathrm{~h}$, and then incubated with the primary antibodies $(1: 2,000$; Cell Signaling Technology, Danvers, MA, USA) overnight at $4^{\circ} \mathrm{C}$. After washing with TBS-T, membrane was incubated with the corresponding HRP-conjugated secondary antibodies (Cell Signaling Technology) for $2 \mathrm{~h}$ at room temperature. Membrane was washed with TBS-T and exposed using enhanced chemiluminescent (ECL) detection kit (CWBio, Inc., Beijing, China).

Caspase activity. BGC823 cells ( $5 \times 10^{7}$ cells/dish) were seeded in $100-\mathrm{mm}$ dishes and treated with $0,20,50,80$ and $100 \mu \mathrm{g} / \mathrm{ml}$ of cecropinXJ for $24 \mathrm{~h}$. After treatment, BGC823 cells were lysed and supernatant was collected. The protein concentration was determined by Bradford protein assay kit. Cellular extracts $(30 \mu \mathrm{g})$ were incubated with $20 \mathrm{ng}$ Ac-DEVD- $p \mathrm{NA}$, Ac-IETD- $p$ NA and Ac-LEHD- $p$ NA for overnight at $37^{\circ} \mathrm{C}$ and 


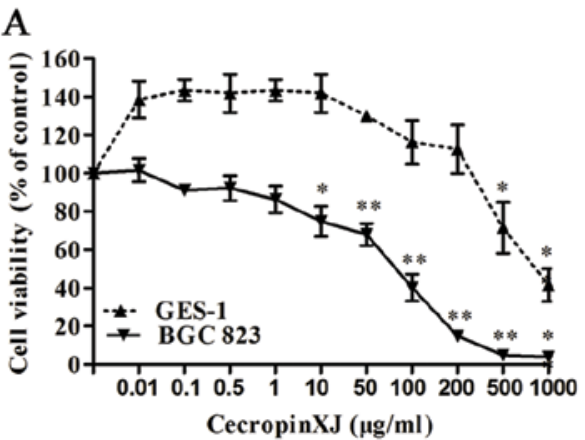

B

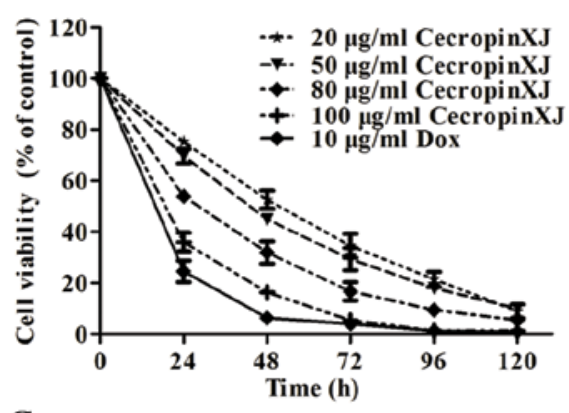

C

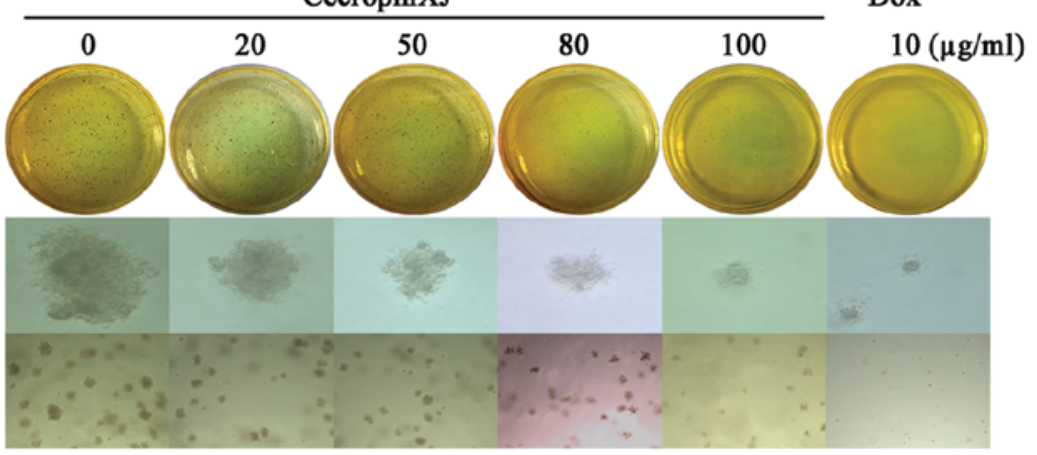

D

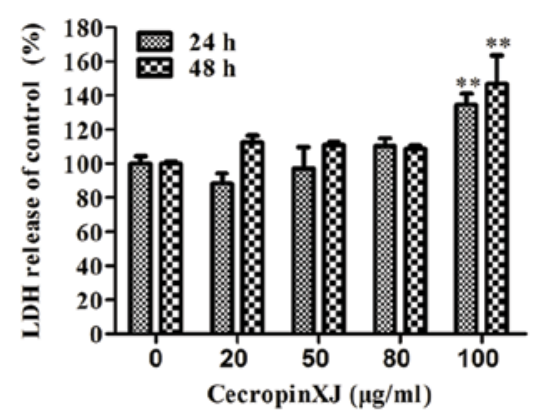

GES-1
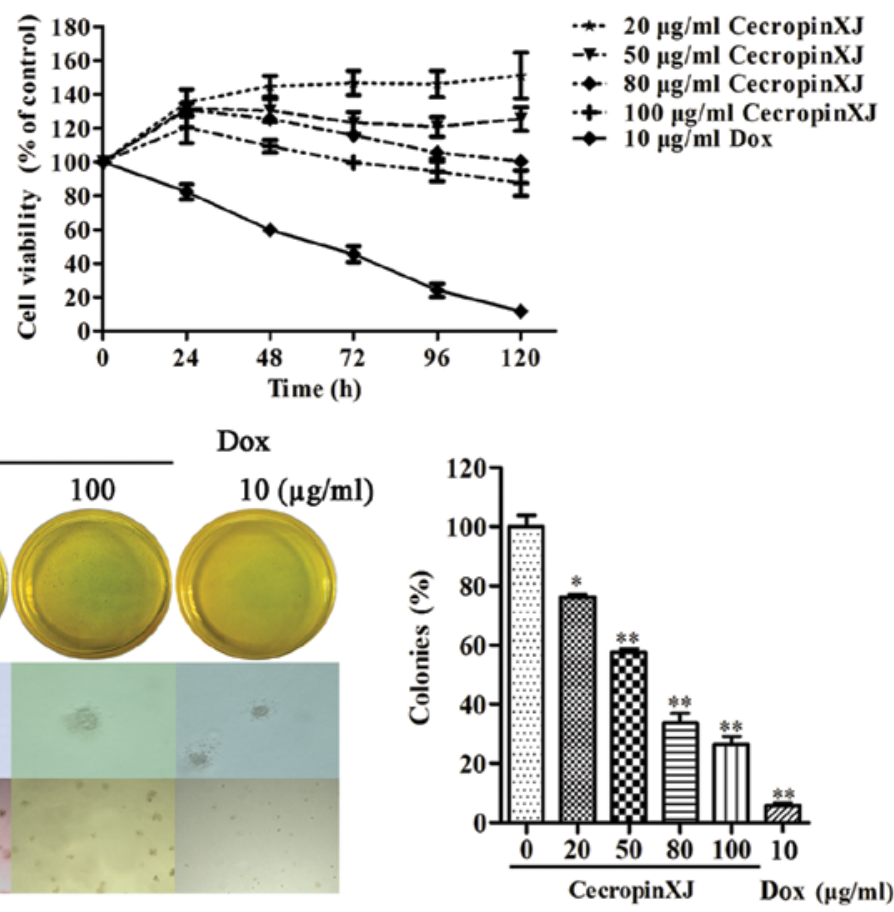

GES-1

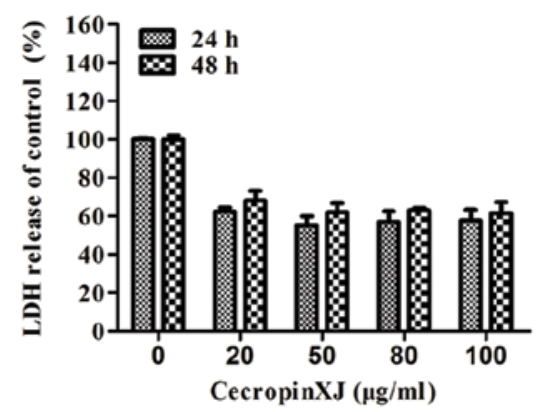

Figure 1. Effects of cecropinXJ on the proliferation of BGC823 cells and GES-1 cells. The proliferation of cells was detected by MTT assay. (A) BGC823 and GES-1 cells were treated with different concentrations (0-1,000 $\mu \mathrm{g} / \mathrm{ml})$ of cecropinXJ for $24 \mathrm{~h}$. (B) BGC823 and GES-1 cells were treated with different concentrations $(20,50,80$ and $100 \mu \mathrm{g} / \mathrm{ml})$ of cecropinXJ for 24, 48, 72, 96 and $120 \mathrm{~h}$. Dox $(10 \mu \mathrm{g} / \mathrm{ml})$ was used as positive control. (C) The colony formation of BGC823 cells. BGC823 cells were treated with different concentrations $(0,20,50,80$ and $100 \mu \mathrm{g} / \mathrm{ml})$ of cecropinXJ and the colonies were detected by soft agar colony formation assay (magnification, upper panel x40 and lower panel x10). (D) The analysis of LDH release. BGC823 cells and GES-1 cells were treated with different concentrations $(0,20,50,80$ and $100 \mu \mathrm{g} / \mathrm{ml})$ of cecropinXJ for 24 and $48 \mathrm{~h}$. The LDH release was detected after treatment. Data are from three independent experiments. ${ }^{*} \mathrm{P}<0.05,{ }^{* *} \mathrm{P}<0.01$.

caspase activity was measured by cleavage of the substrates to pNA, the absorbance was measured at $405 \mathrm{~nm}$. Relative caspase activity was calculated as a ratio $\mathrm{OD}_{\text {treated }} / \mathrm{OD}_{\text {untreated. }}$

Xenograft tumor model. Four-week-old athymic nude female mice (BALB/c nu/nu) were purchased from the Beijing
Laboratory Animal Research Center (Beijing, China) and received pathogen-free water and food. The mice were inoculated subcutaneously with BGC823 cells $\left(5 \times 10^{6}\right)$ in $0.1 \mathrm{ml}$ of PBS. All the mice developed tumors at day 5 and were randomized into two groups $(n=6)$. The experiment group was peritumorally injected with $0.1 \mathrm{ml}$ cecropinXJ $(100 \mu \mathrm{g})$ 
A

$0 \mu \mathrm{g} / \mathrm{ml}$

$20 \mu \mathrm{g} / \mathrm{ml}$

$50 \mu \mathrm{g} / \mathrm{ml}$

$100 \mu \mathrm{g} / \mathrm{ml}$
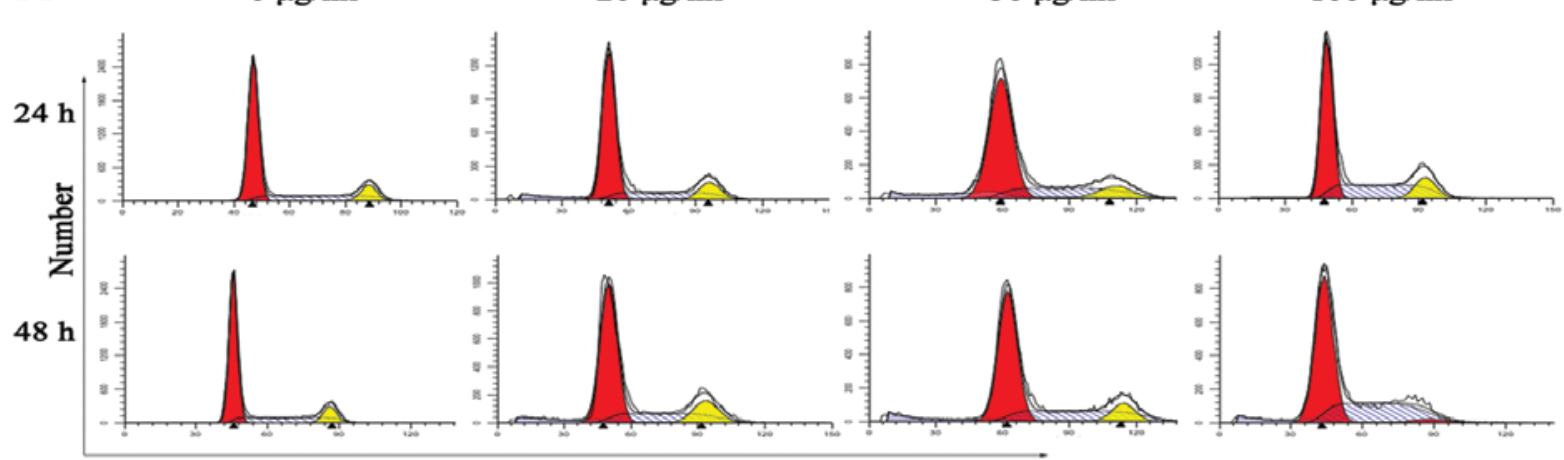

B

DNA content
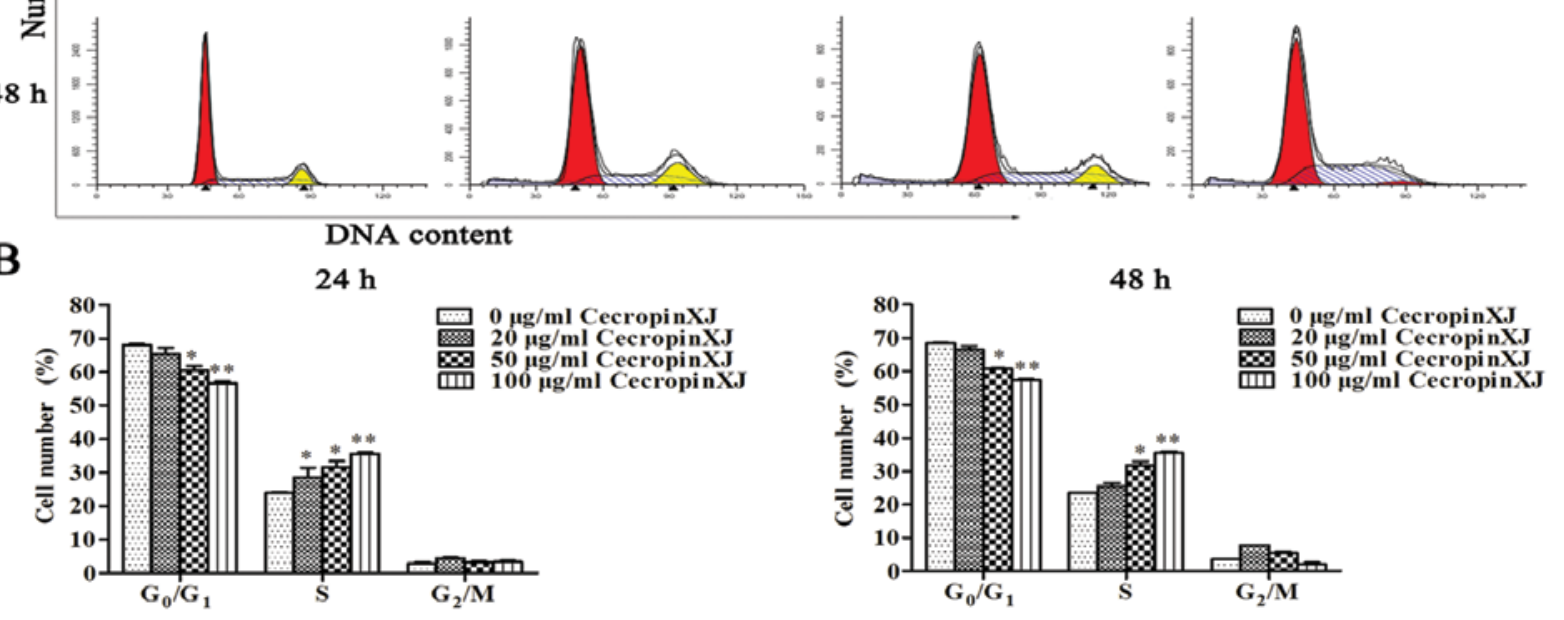

Figure 2. CecropinXJ induces cell cycle arrest at S-phase in BGC823 cells. BGC823 cells were treated with different concentrations of cecropinXJ $(0,20,50$ and $100 \mu \mathrm{g} / \mathrm{ml}$ ) for 24 and $48 \mathrm{~h}$. (A) The cell cycle distribution of the treated cells were evaluated by flow cytometry. (B) The percentage (mean \pm SD) of cells in each phase is shown. Data are from three independent experiments. ${ }^{*} \mathrm{P}<0.05,{ }^{* *} \mathrm{P}<0.01$.

five times per week (from Monday to Friday) during a 2-week period and the control group was injected with $0.1 \mathrm{ml}$ of BSA $(100 \mu \mathrm{g})$. Mouse weight and tumor size were measured every day. After two weeks, mice were sacrificed and tumors were dissected. After weighing, tumors were fixed in $10 \%$ formalin and embedded in paraffin. Sections were stained with hematoxylin and eosin.

TUNEL staining. The TUNEL staining assay was performed according to the manufacturer's instructions (Biobox, Nanjing, China). Paraffin-embedded tissue slides were dewaxed and rehydrated by heating at $60^{\circ} \mathrm{C}$, followed by washing in xylene and rehydration through a graded series of ethanol and double-distilled water. Tissue sections were incubated with proteinase $\mathrm{K}(20 \mu \mathrm{g} / \mathrm{ml})$ at room temperature for $15 \mathrm{~min}$ and with $3 \% \mathrm{H}_{2} \mathrm{O}_{2}$ for $10 \mathrm{~min}$. Then sections were incubated with the TdT enzyme at $37^{\circ} \mathrm{C}$ for $60 \mathrm{~min}$. After incubation with streptavidin-HRP solution in darkness for $30 \mathrm{~min}$, the sections were stained with 3,3-diaminobenzidine (DAB) substrate for $2 \mathrm{~min}$ and then counterstained with hematoxylin.

Immunohistochemistry. Paraffin-embedded tissue were cut four-micrometer-thick in consecutive sections and processed for immunohistochemistry for CD31, CD34, basic fibroblast growth factor (bFGF), vascular endothelial growth factor (VEGF) and von Willebrand factor (VWF) (Biosynthesis, Beijing, China). Tissue sections were deparaffinized, dewaxed and rehydrated by heating at $60^{\circ} \mathrm{C}$, followed by washing with $\mathrm{PBS} / \mathrm{T}$. Antigen retrieval was carried out in a microwave oven for $10 \mathrm{~min}$. The sections were blocked with $10 \%$ goat serum (formulated with $3 \% \mathrm{BSA}$ ) at $37^{\circ} \mathrm{C}$ for $15 \mathrm{~min}$ and washed thrice with PBS. The primary antibodies against angiogenesisassociated proteins with 1:200 dilution were incubated for
$1 \mathrm{~h}$. After washing with TBS-T, slides were incubated with the HRP-conjugated secondary antibodies for $1 \mathrm{~h}$ at room temperature. Sections were stained with DAB, counterstained with hematoxylin and mounted. The immunohistochemical staining was observed under light microscope.

Statistical analysis. Data are expressed as the mean \pm SD. Statistical analyses were performed using Student's t-test. Values of $\mathrm{P}<0.05$ or 0.01 was considered statistically significant and indicated in the figures with * and **, respectively.

\section{Results}

CecropinXJ effectively suppress the proliferation of gastric cancer BGC823 cells. We first examined whether cecropinXJ could suppress the proliferation of gastric adenocarcinoma BGC823 cells via MTT assay. Normal gastric epithelial cell GES-1 was used as control. Compared to GES-1 cells, the proliferation of BGC 823 cells was significantly inhibited by cecropinXJ in dose- and time-dependent manner (Fig. 1A and B). Dox suppressed the growth of both types of cells. The inhibitory effects of $100 \mu \mathrm{g} / \mathrm{ml}$ cecropinXJ on BGC823 cells were similar to $10 \mu \mathrm{g} / \mathrm{ml}$ Dox (Fig. 1B). When the concentration of cecropinXJ was $<500 \mu \mathrm{g} / \mathrm{ml}$, the growth of GES-1 cells was not impaired by the cecropinXJ treatment compared to without cecropinXJ treatment (Fig. 1A).

The soft agar colony formation assay showed that cecropinXJ treatment dose-dependently inhibited the colony formation and colony growth of BGC 823 cells. The colony formation ratio was only $(26.46 \pm 4.65 \%)$ under $100 \mu \mathrm{g} / \mathrm{ml}$ cecropinXJ treatment (Fig. 1C). These results suggest that cecropinXJ might have a long-term effect on the proliferation of BGC823 cells. 
Many AMPs can destroy the lipid membrane and lead to cell lysis and death (24). We investigated whether cecropinXJ could destroy cell membrane through measuring the released cytoplasmic enzyme LDH into the cell culture supernatant. Compared with untreated group, cecropinXJ treatment did not significantly increase LDH release of BGC823 cells either for 24 or $48 \mathrm{~h}$ until the concentration of cecropinXJ reached up to $100 \mu \mathrm{g} / \mathrm{ml}$, suggesting that high concentration of cecropinXJ treatment destroyed the integrity of plasma membrane in BGC823 cells but low concentration of cecropinXJ did not. CecropinXJ did not affect the plasma membrane in GES-1 cells.

CecropinXJ arrests the cell cycle of BGC823 cells at S phase. To determine whether cecropinXJ affects the cell cycle of BGC823 cells, the cell cycle distribution of cecropinXJtreated BGC823 cells was analyzed by flow cytometry. Upon cecropinXJ treatment, the percentage of cells at $\mathrm{G}_{0} / \mathrm{G}_{1}$-phase significantly decreased $(56.67$ and $57.28 \%$ in the $100 \mu \mathrm{g} / \mathrm{ml}$ cecropinXJ treatment for 24 and $48 \mathrm{~h}$, respectively, vs. 68.14 and $68.52 \%$ in the control group), whereas the percentage of cells at S-phase significantly increased (35.65 and $35.75 \%$ in the $100 \mu \mathrm{g} / \mathrm{ml}$ cecropinXJ treatment for 24 and $48 \mathrm{~h}$, respectively, vs. 23.87 and $23.48 \%$ in the control group) (Fig. 2). BGC823 cells with cecropinXJ treatment achieved peak apoptosis. These results indicated that cecropinXJ induced S-phase arrest and apoptosis in a dose-dependent manner.

CecropinXJ dose-dependently induces apoptosis of BGC823 cells. The above results showed that both low $(<80 \mu \mathrm{g} / \mathrm{ml})$ and high concentration of cecropinXJ could inhibit BGC823 cell proliferation with or without damage of plasma membrane. To investigate the mechanism of cecropinXJ-mediated proliferation inhibition of BGC 823 cells, BGC 823 cells were treated with different concentrations of cecropinXJ for 24 or $48 \mathrm{~h}$ and stained with Annexin V-FITC and PI. The samples were analyzed by flow cytometry. CecropinXJ treatment dosedependently increased apoptosis of BGC 823 cells at both early and late stages. The apoptosis of BGC823 cells was increased from $(4.88 \pm 2.53 \%)$ (untreated) to $(39.56 \pm 4.36 \%)(100 \mu \mathrm{g} / \mathrm{ml}$ cecropinXJ treated) for $24 \mathrm{~h}$. Compared to $24 \mathrm{~h}$, the apoptosis of BGC823 cells was also increased $48 \mathrm{~h}$ after cecropinXJ treatment. Furthermore, $100 \mu \mathrm{g} / \mathrm{ml}$ cecropinXJ treatment induced necrosis of BGC823 cells compared to other groups for both 24 and $48 \mathrm{~h}$ (Fig. 3A and B).

Morphological characteristics of apoptosis include chromatin condensation, DNA fragmentation and membrane blebbing (25). Nuclear morphology was observed by Hoechst 33258 staining. As shown in Fig. 3C, the untreated cells were round and homogeneously stained, whereas cecropinXJ-treated cells showed obvious chromatin condensation and fragmentation. Moreover, the numbers of apoptotic nuclei containing condensed chromatin increased significantly with the increased concentration of cecropinXJ.

Ultrastructure of BGC823 cells was observed using transmission electron microscopy and revealed that cecropinXJ induced significantly morphological changes. The untreated BGC823 cells showed intact membrane, normal nucleus and integrated mitochondria. However, cecropinXJ-treated cells showed nuclear heterochromatin and condensed chro- matin distribution around the nuclear membrane. Moreover, mitochondria was osteoporosized and swollen and cristae disappeared (Fig. 3D). Taken together, these results suggested that cecropinXJ induced apoptosis of BGC823 cells.

CecropinXJ promotes ROS production and decreases mitochondrial membrane potential $\left(\Delta \psi_{m}\right)$. It has been reported that cancer cell apoptosis induced by cecropins may be due to mitochondrial dysfunction and overproduction of ROS (26). Intracellular ROS production and loss of $\Delta \psi_{\mathrm{m}}$ cause mitochondrial membrane depolarization and trigger a cascade of mitochondrion-dependent apoptotic signaling (27). The ROS level and the $\Delta \psi_{\mathrm{m}}$ were measured by flow cytometry using $\mathrm{H}_{2}$ DCF-DA and $\operatorname{DiOC}_{6}(3)$, respectively. In this assay, cecropinXJ increased ROS generation in dose- and timedependent manner. Moreover, cecropinXJ-treated BGC823 cells significantly decreased their $\Delta \psi_{\mathrm{m}}$ (Fig. 4).

CecropinXJ induces apoptosis through activation of caspase pathway. It is well known that proteins in the caspasefamily and Bcl-2-family play critical roles in the apoptosis process (28). To investigate whether caspase-family and Bcl-2-family proteins were involved in cecropinXJ-induced apoptosis, we measured the expression and activation of these apoptosis-associated proteins by qRT-PCR and western blot analysis. According to the results of the western blot analysis, these enzymes including caspase-3 (effector caspase), -8 and -9 (initiator caspase) were all cleaved. Moreover, cecropinXJ treatment dose-dependently increased the expression of Bax and cytochrome $c$ at both RNA and protein levels but decreased the expression of anti-apoptotic molecule Bcl-2 (Fig. 5A and $\mathrm{B}$ ). The Bax/Bcl-2 ratio increased in BGC823 cells, suggesting that these proteins were involved in cecropin XJinduced apoptosis.

The activities of caspase- $3,-8$ and -9 were further detected in cecropinXJ-treated cells using the colorimetric tetrapeptide substrates Ac-DEVD- $p$ NA,Ac-IETD- $p$ NA and Ac-LEHD- $p$ NA, which have been shown to be specific for caspase-3-, caspase-8and caspase-9-like enzymatic activity, respectively (29). After $100 \mu \mathrm{g} / \mathrm{ml}$ cecropinXJ treatment for $24 \mathrm{~h}$, the activities of caspase-3, -8 and -9 were increased 2.3-, 1.3- and 1.3-fold compared to untreated control (Fig. 5C). Before cecropinXJ treatment, adding the caspase inhibitors (Ac-VAD-fmk for pan-caspase, Ac-DEVE-fmk for caspase-3 and Ac-LEHD-fmk for caspase-9) significantly reduced cecropinXJ-induced cell death $(\mathrm{P}<0.01)$, but caspase-8 inhibitor had no effect (Fig. 5D). These results suggest that cecropin XJ might induce apoptosis of BGC823 cells via activation of caspase- 3 and -9 .

CecropinXJ inhibits tumor growth in vivo. To investigate whether cecropinXJ could suppress the growth of BGC823 cells in vivo, mice were injected with BGC823 cells and treated with BSA (control group) or cecropinXJ on day 7. Twelve days after treatment, the tumors were removed from these animals and their volumes and weights were measured (Fig. 6). The tumor volume and tumor weight in mice treated with cecropinXJ were markedly reduced compared with BSA. CecropinXJ appeared to be non-toxic to normal cells, and there were no notable side-effects on the body weight of mice (the mice had tumors) at the end of the experiment (Fig. 6D). 
A
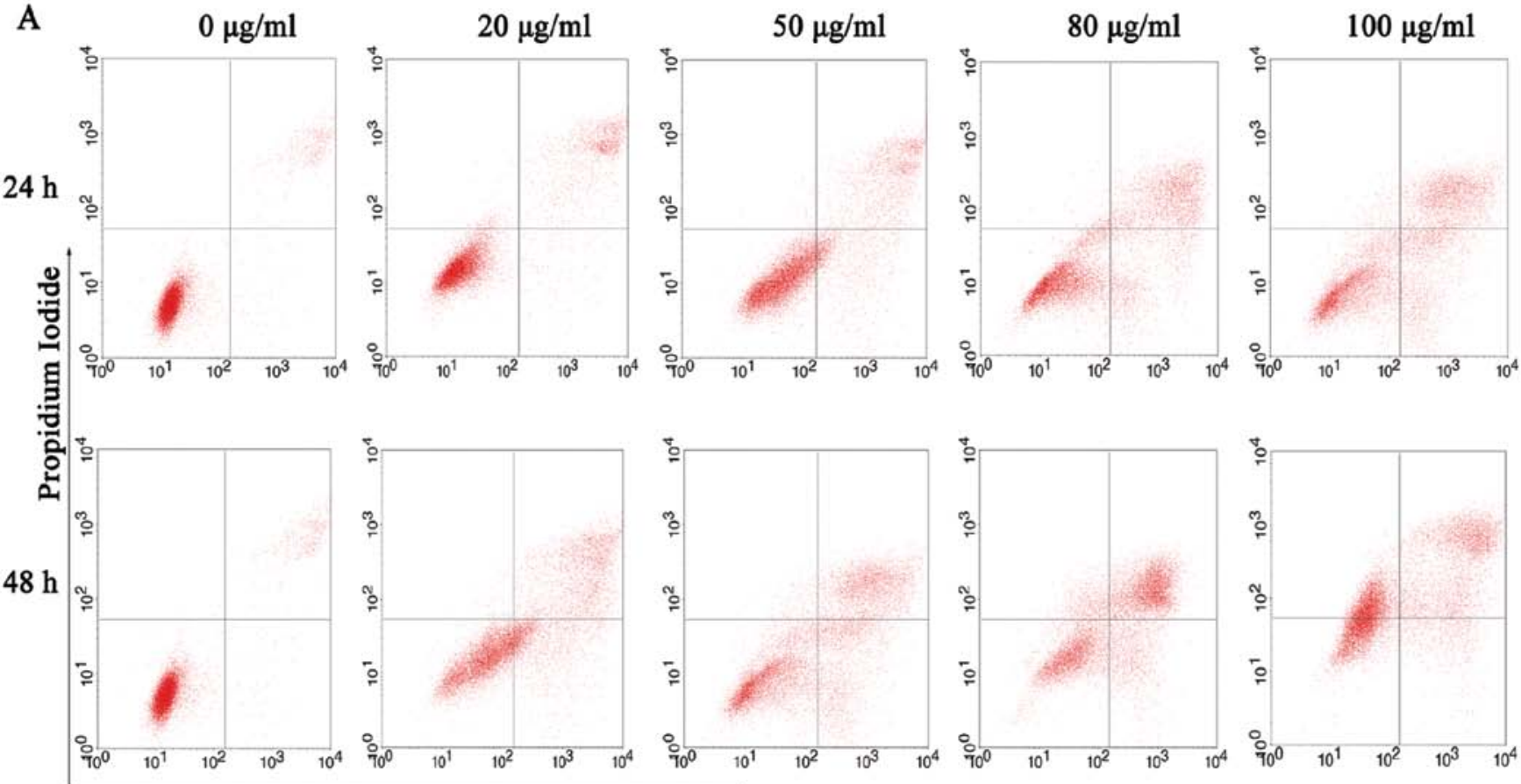

B

$24 \mathrm{~h}$

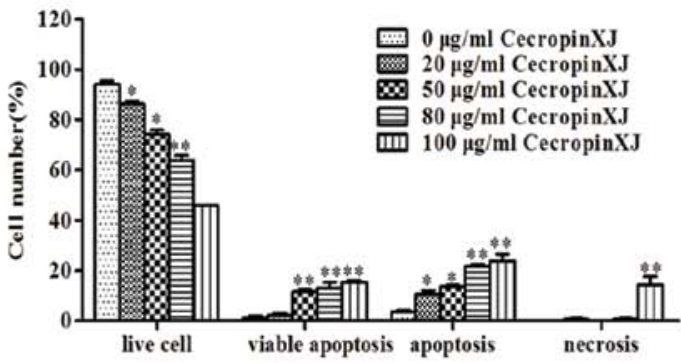

C

$0 \mu \mathrm{g} / \mathrm{ml} \quad 20 \mu \mathrm{g} / \mathrm{ml} \quad 50 \mu \mathrm{g} / \mathrm{ml} \quad 80 \mu \mathrm{g} / \mathrm{ml} \quad 100 \mu \mathrm{g} / \mathrm{ml}$

White

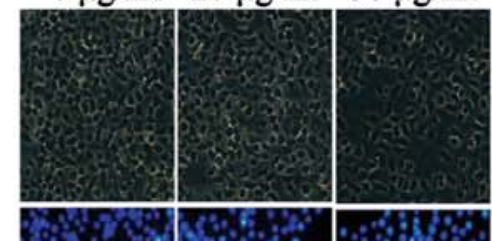

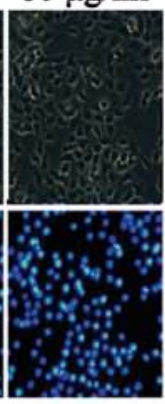

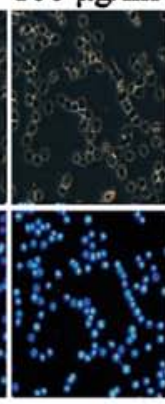

$48 \mathrm{~h}$

Hoechst 33258
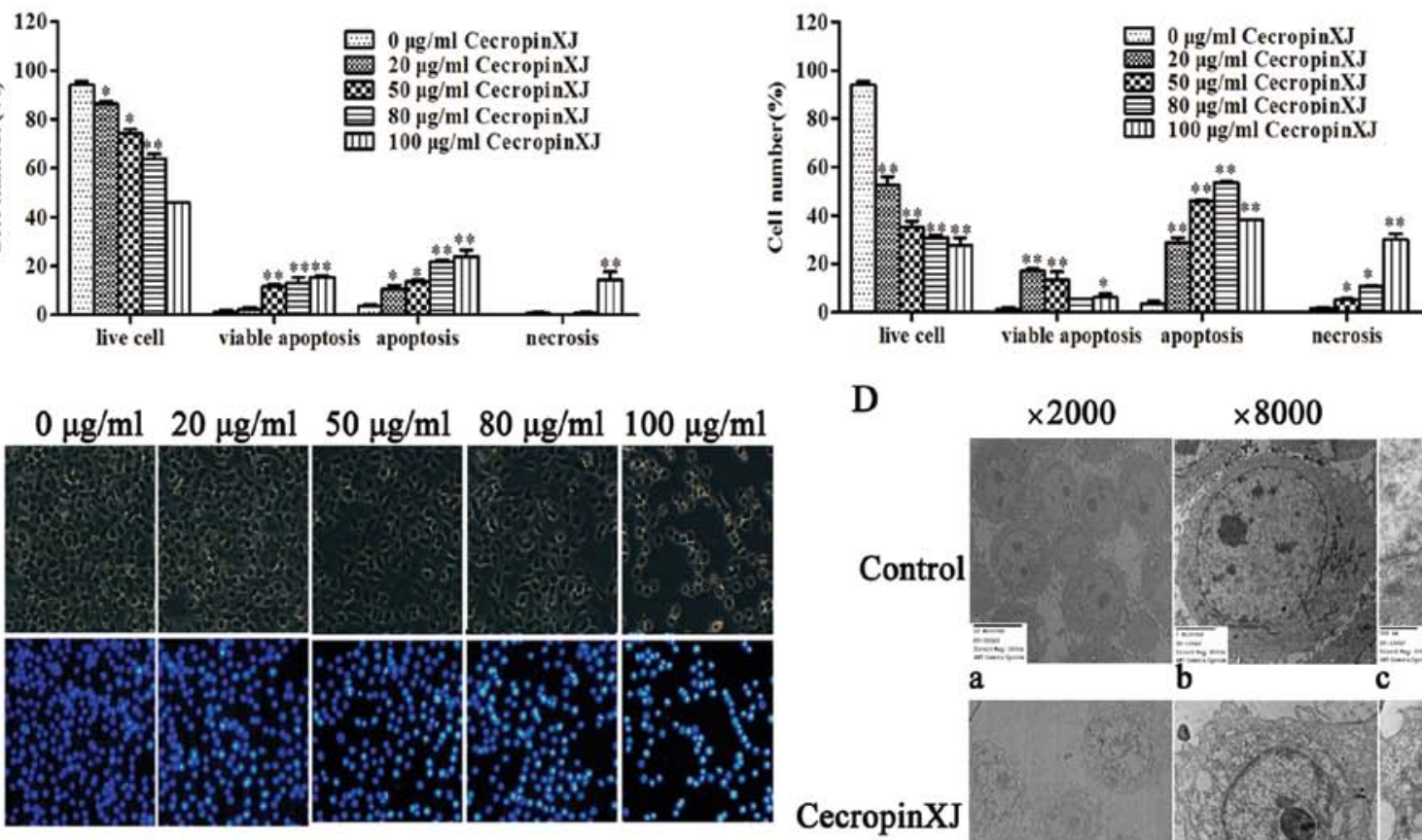

D

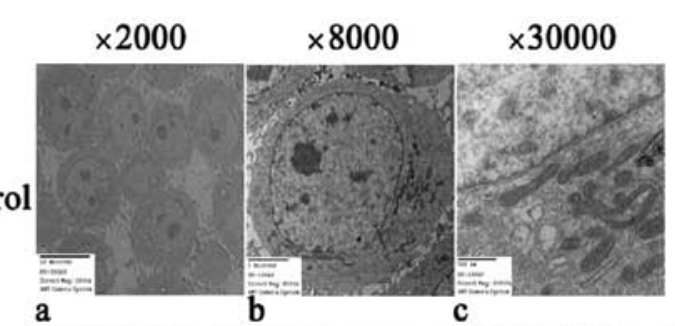

a

c

CecropinXJ

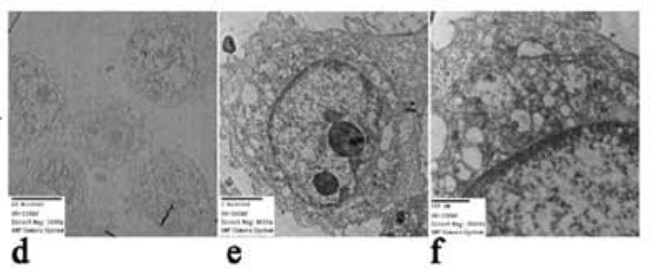

Figure 3. CecropinXJ induces apoptosis in BGC823 cells. (A) BGC823 cells were treated with cecropinXJ (0, 20, 50, 80 and $100 \mu \mathrm{g} / \mathrm{ml})$ for 24 and $48 \mathrm{~h}$. After treatment, cells were stained with Annexin V-FITC/PI and analyzed by flow cytometry. The percentage (mean \pm SD) of apoptotic cells is shown. Data are from three independent experiments. (C) The nuclear morphology of BGC823 cells. BGC823 cells were treated with cecropinXJ (0, $20,50,80$ and $100 \mu \mathrm{g} / \mathrm{ml})$ for $24 \mathrm{~h}$ and stained with Hoechst 33258. Changes in apoptotic nuclear morphology were observed by fluorescent microscopy (magnification, x10). (D) BGC823 cells were treated with $0 \mu \mathrm{g} / \mathrm{ml}$ ( $\mathrm{a}, \mathrm{b}$ and $\mathrm{c}$ ) and $100 \mu \mathrm{g} / \mathrm{ml}$ CecropinXJ (d, e and f) for $24 \mathrm{~h}$ and the morphology was observed by a transmission electron microscope (TEM) under different magnifications (a and d, $\mathrm{x} 2,000$; b and e $\mathrm{x} 8,000$; $\mathrm{c}$ and $\mathrm{f}, \mathrm{x} 30,000$ ). Representative data are shown from one of three independent experiments. ${ }^{*} \mathrm{P}<0.05,{ }^{* *} \mathrm{P}<0.01$.

Moreover, we observed abundant apoptotic cells in tumors from cecropinXJ-treated group via H\&E and TUNEL staining (Fig. 6E).
The expression of caspase- $3,-8,-9, \mathrm{Bax}, \mathrm{Bcl}-2$ and cytochrome $c$ in tumors was further detected. We found that cecropinXJ treatment increased the expression of caspase-3, 
A
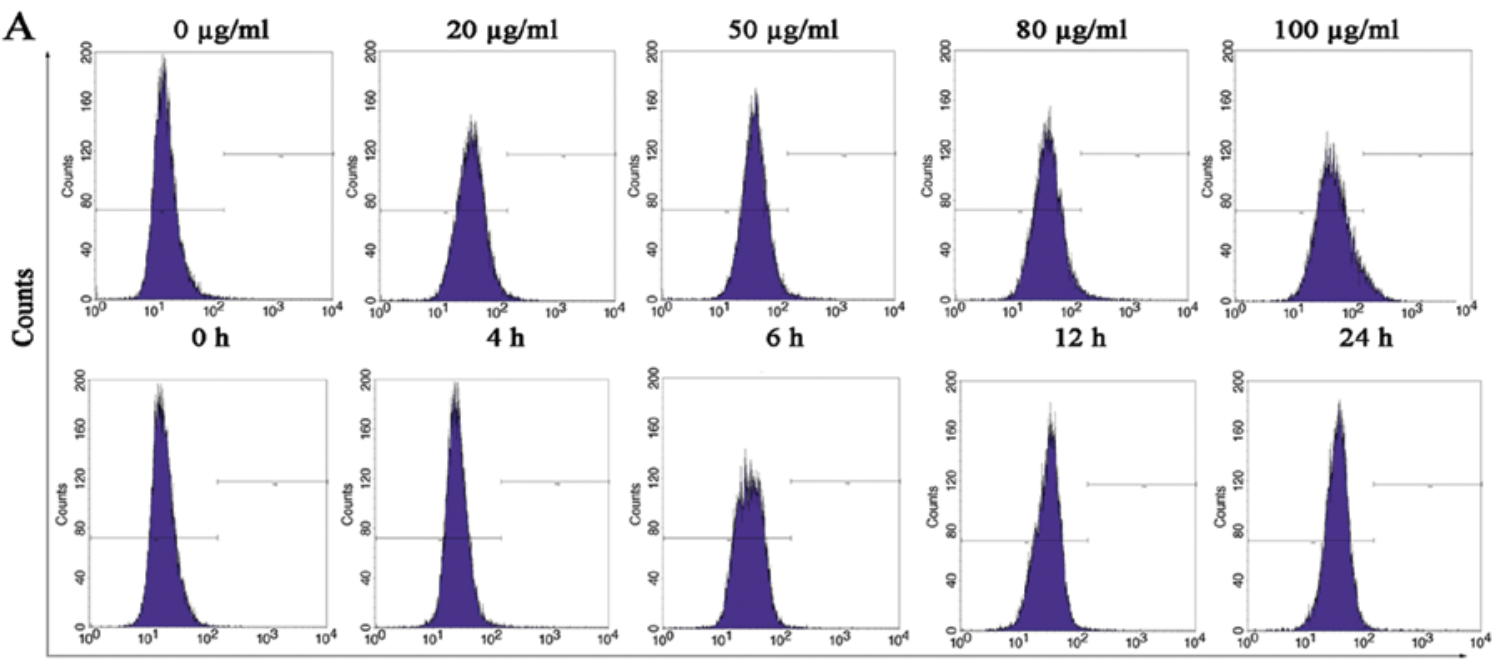

B
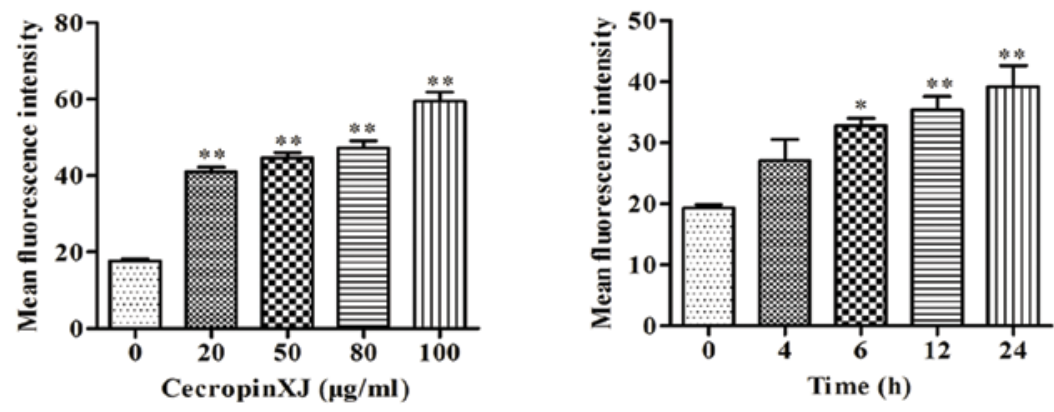

C
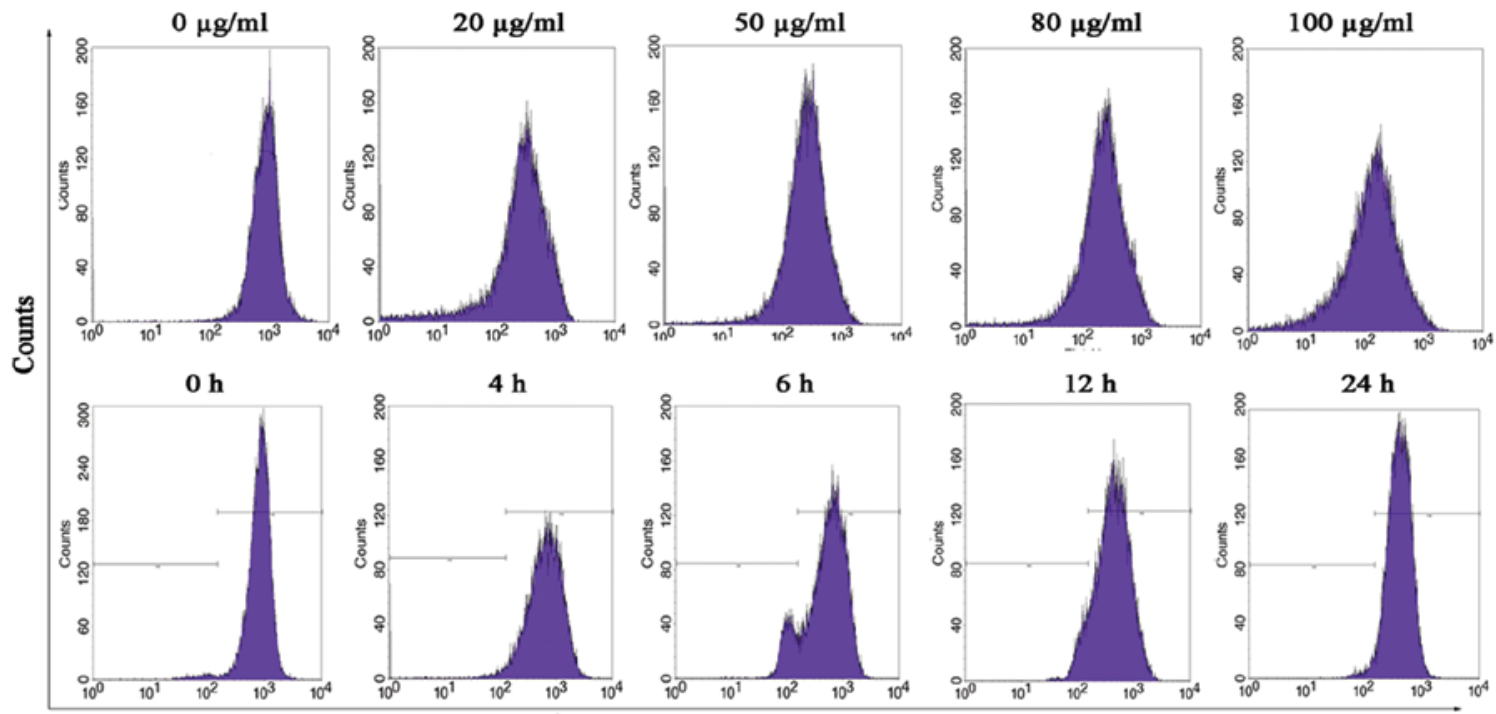

D
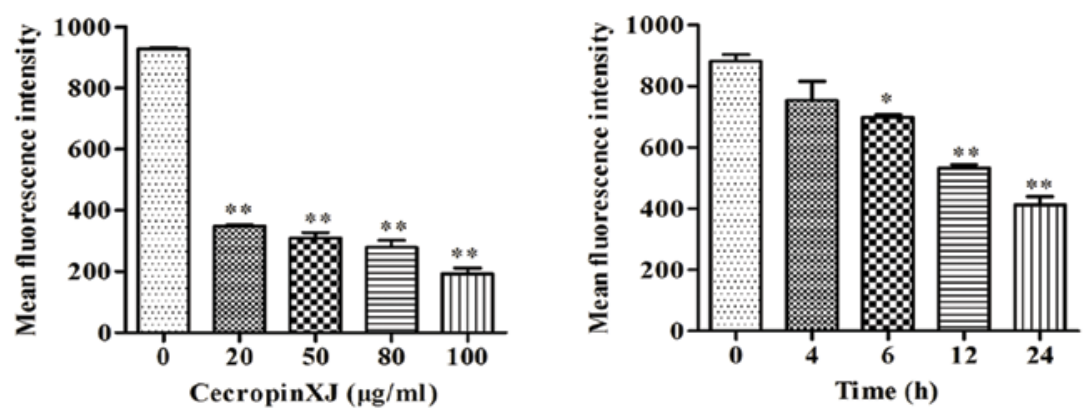

Figure 4. CecropinXJ promotes ROS production and decreases mitochondrial membrane potential $\left(\Delta \psi_{\mathrm{m}}\right)$ in BGC 823 cells. BGC 823 cells were treated with different concentrations $(0,20,50,80$ and $100 \mu \mathrm{g} / \mathrm{ml})$ of cecropinXJ for $24 \mathrm{~h}$ or $100 \mu \mathrm{g} / \mathrm{ml}$ cecropinXJ for $0,4,6,12$ and $24 \mathrm{~h}$. ROS production $(\mathrm{A})$ and $\Delta \psi \mathrm{m}$ (C) were detected by $\mathrm{DCFH}_{2}$-DA and $\mathrm{DiOC}_{6}(3)$, respectively, and analyzed by flow cytometry. (B and D) Mean fluorescence intensity (mean \pm SD) of ROS and $\Delta \psi_{\mathrm{m}}$ is shown in $\mathrm{B}$ and $\mathrm{D}$, respectively. Data are from three independent experiments. ${ }^{*} \mathrm{P}<0.05,{ }^{* * *} \mathrm{P}<0.01$. 
A
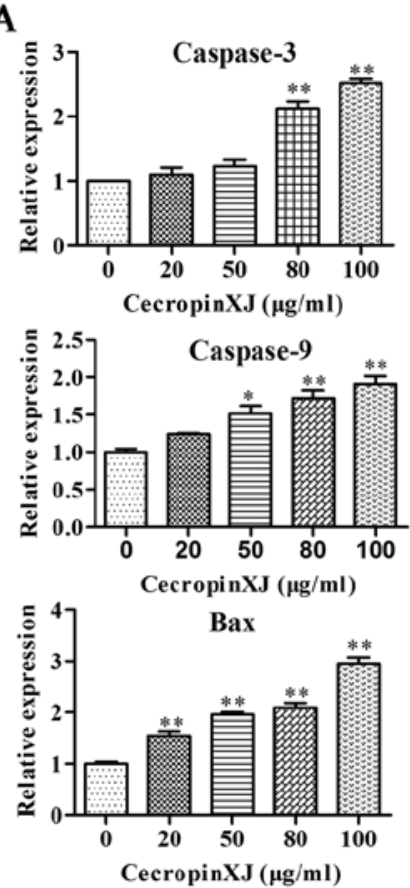

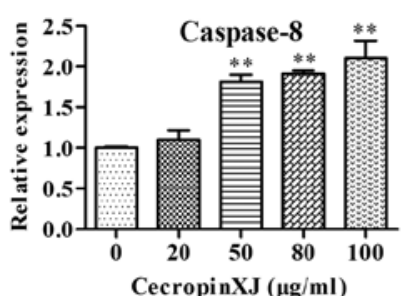

Bcl-2
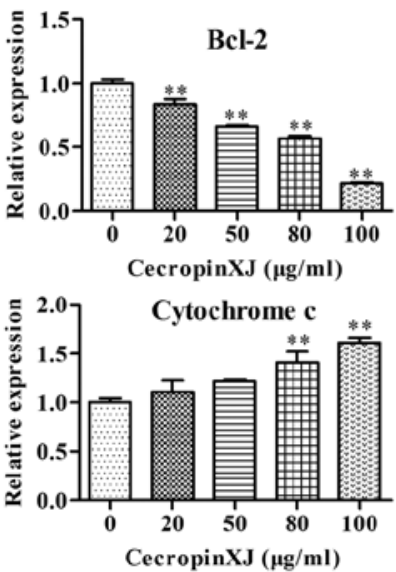

B

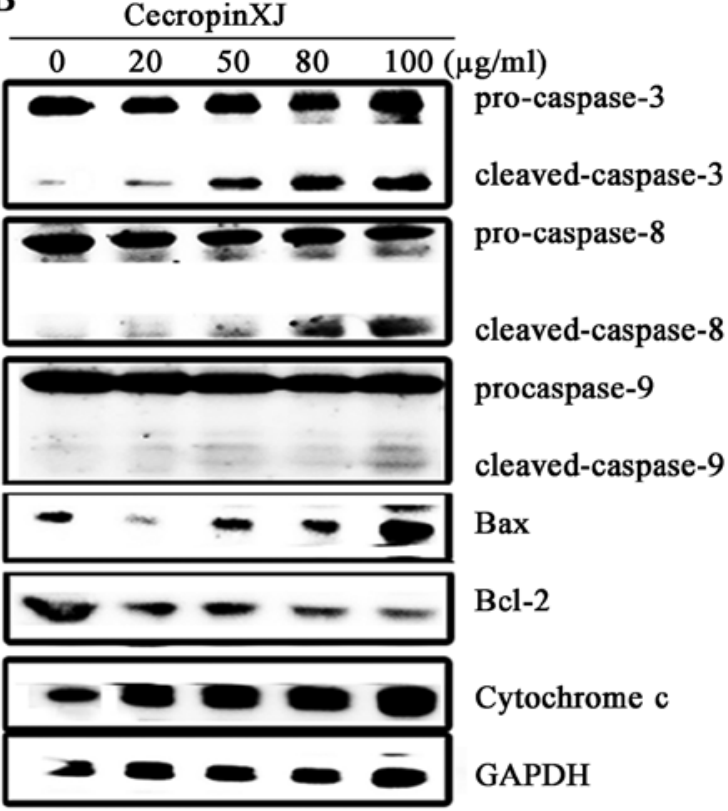

C
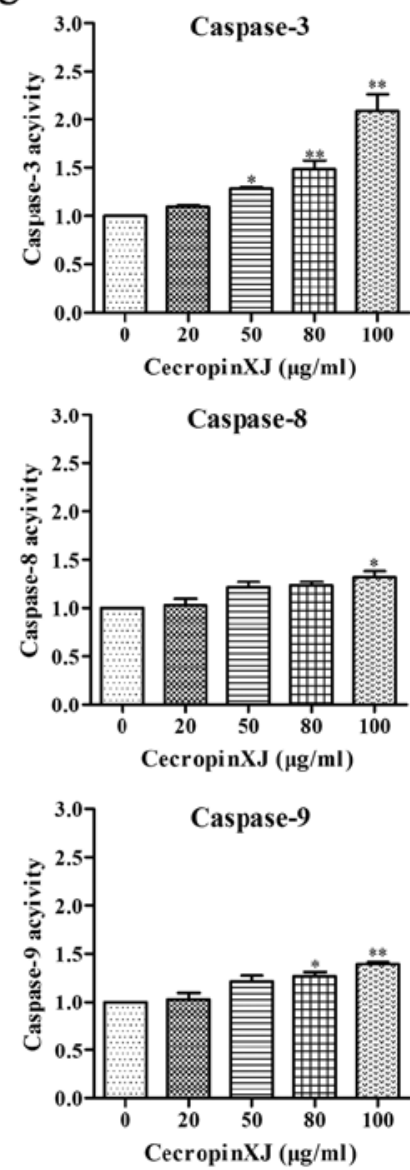

D
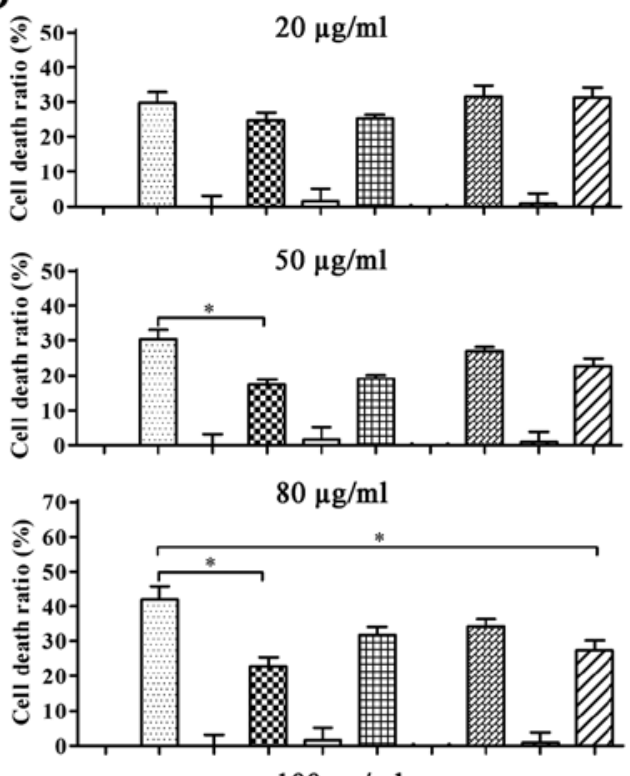

$100 \mu \mathrm{g} / \mathrm{ml}$

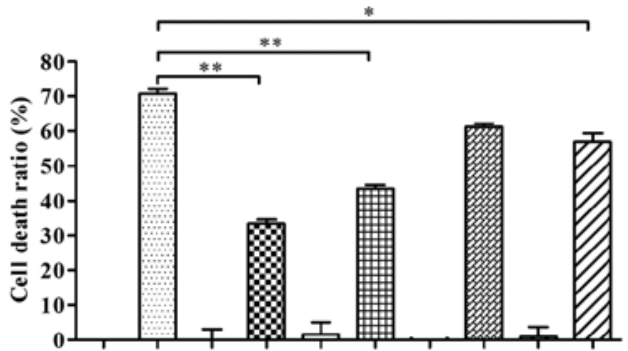

CecropinXJ -+-+-+-+-+

Ac-VAD-fmk --++-----

Ac-DEVE-fmk - $- \pm \pm-\overline{+}=--$

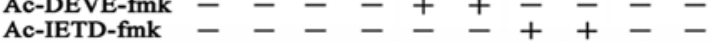

Figure 5. CecropinXJ induces caspase-dependent apoptosis in BGC823 cells. BGC823 cells were treated with various concentrations of cecropinXJ (0, 20, 50, 80 and $100 \mu \mathrm{g} / \mathrm{ml}$ ) for $24 \mathrm{~h}$ and the expression and activity of caspases were detected. (A) The gene expression of apoptosis-associated proteins was detected by qRT-PCR. GAPDH was used as a reference gene. (B) The protein levels of apoptosis-associated proteins were detected by western blot analysis. (C) The activities of caspase-3, caspase- 8 and caspase-9 was measured. (D) The effects of caspase inhibitors on cecropinXJ-induced cell death. BGC823 cells were pre-treated with the pan-caspase inhibitor and specific caspase inhibitors and then treated with cecropinXJ. The cell death ratio (\%) of BGC823 cells was detected by MTT assay. The data are shown mean \pm SD. ${ }^{*} \mathrm{P}<0.05,{ }^{* *} \mathrm{P}<0.01$. 
A

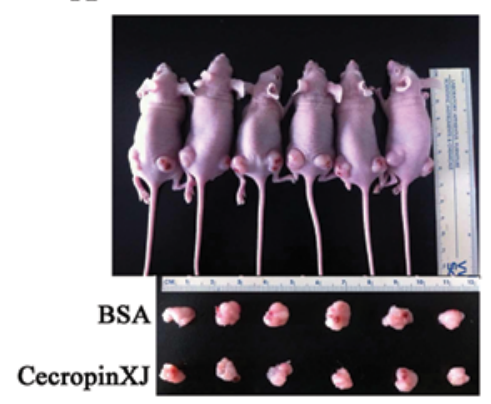

C

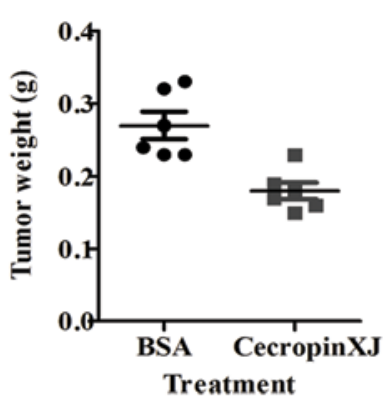

B

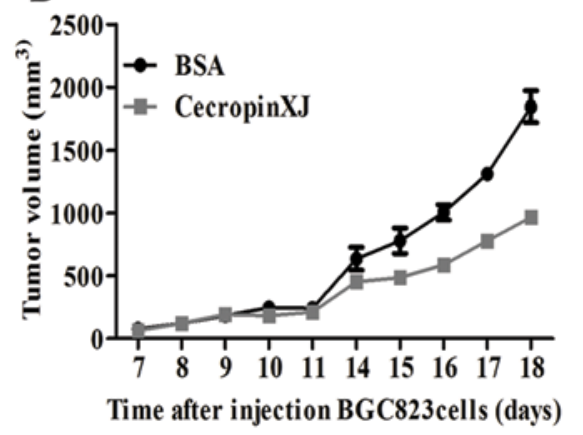

E

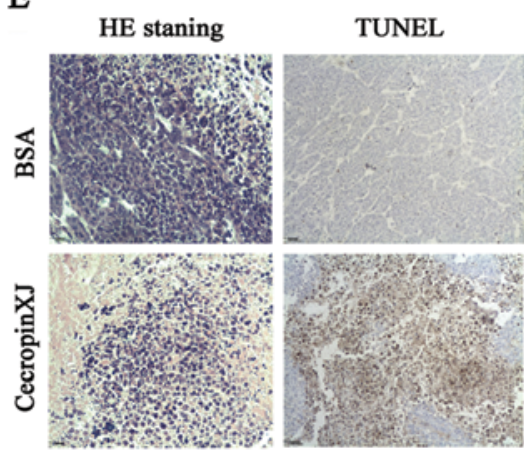

D

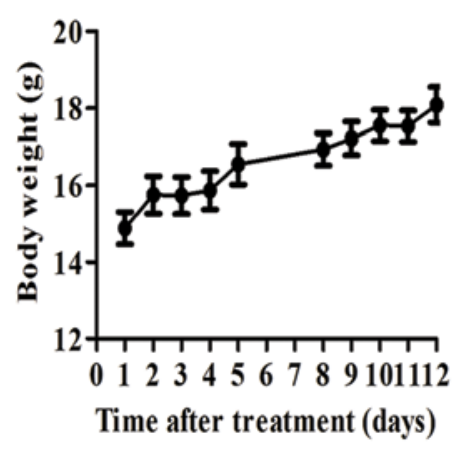

F
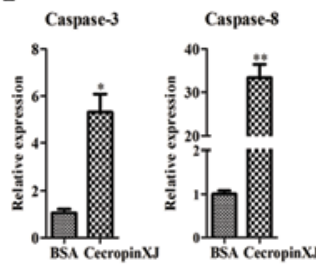

Bax
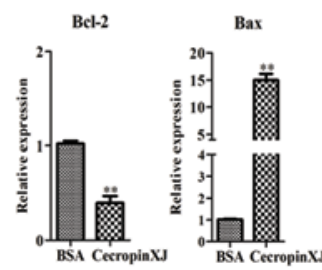

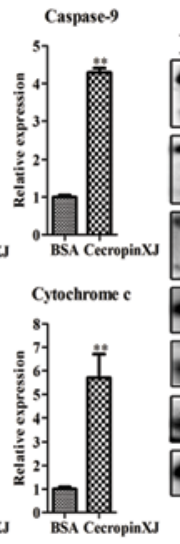

BSA CecropinXJ

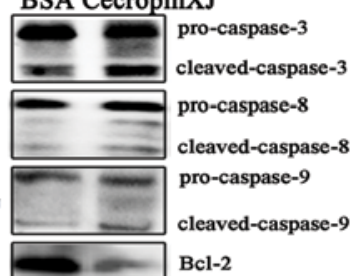

BŚA CecropinXJ

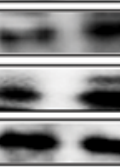

Bax

Cytochrome c

GAPDH

Figure 6. CecropinXJ inhibits tumor growth in nude BALB/c mice. Nude mice $(n=6)$ were inoculated with BGC823 cells subcutaneously on both sides of the back. After 7 days, the right and left sides were peritumorally treated with $100 \mu \mathrm{g}$ cecropinXJ and BSA in $0.1 \mathrm{ml}$ PBS, respectively, five times per week. After 12 days, mice were sacrificed and tumors were isolated. After weighing, tumors were fixed with $10 \%$ formalin. (A) The effects of cecropinXJ on tumor size after treatment. (B) Tumor size was measure 5 times per weeks for two weeks. Data (mean \pm SD) are plotted as the tumor volume (mm ${ }^{3}$ ). (C) The weight of tumors on day 12 after treatment. (D) The weight of mice was measured after treatment. (E) H\&E and TUNEL staining of tumor slices. (F) The gene expression of apoptosis-associated proteins in tumor was detected by qRT-PCR and western blot analysis. GAPDH was used as a reference gene. ${ }^{*} \mathrm{P}<0.05$, $^{* *} \mathrm{P}<0.01$.

$-8,-9$, Bax and cytochrome $c$ but decreased the expression of Bcl-2, which was consistent with the in vitro data.

CecropinXJ inhibits the expression of angiogenesis-associated proteins in vitro and in vivo. Tumor angiogenesis is initiated by production of angiogenic growth factors from tumor, stromal and infiltrating inflammatory cells (30). Upon cecropinXJ treatment, we examined the expressions of angiogenesis-associated proteins including CD31, CD34, bFGF, VEGF and VWF in BGC823 cells and tumors by qRT-PCR and western blot analysis. As shown in Fig. 7, the expression of all these proteins in BGC823 cells treated with cecropinXJ was downregulated at both RNA and protein levels. Importantly, the expression of all these proteins in tumors treated with cecropinXJ was also decreased by immunohistochemical staining. The results suggest that cecropinXJ could inhibit tumor angiogenesis.

\section{Discussion}

Chemotherapy alone shows low efficacy that may be due to drug resistance, and severe side-effects that affect normal mammalian cells $(31,32)$. Since Moore et al (33) first found that Cecropin B possessed potent anticancer activity in mammalian cancer cells, a large body of evidence shows that cecropin families exerted cytotoxic effects on a number of tumor derived cell lines in vitro and exhibited inhibitory effects on tumor growth in vivo, such as human breast adenocarcinoma (34) and hepatocellular carcinoma (35). Cecropins contained amphipathic $\alpha$-helices that allowed them to target non-polar lipid cell membranes and formed ion-permeable channels to result in cell depolarization, irreversible cytolysis and final cell death (36). The characteristic of cecropins may avoid drug resistance.

Previous study has determined that the cecropins from Chinese oak silkworm possess effective antitumor activity against the human colon adenocarcinoma cells but without cytotoxicity against normal human gastric epithelial cells (GES-1), suggesting cecropins could specifically kill tumor cells (37). Other evidence also showed that cecropins could suppress the growth of tumor cells such as leukemia cells, but have no hemolytic activity against human erythrocytes and no or little toxicity to normal mammalian cells (38). Consistently, we observed that cecropinXJ inhibited the proliferation of BGC823 cells but did not affect normal GES-1 cells. The inhibitory effects of $100 \mu \mathrm{g} / \mathrm{ml}$ cecropinXJ on the proliferation of BGC823 cells was similar to $10 \mu \mathrm{g} / \mathrm{ml}$ Dox. The specific effects on cancer cells might be attributed to the nature of cecropins contained cationic sequence to interact with non-polar anionic plasma membranes of cancer cells (39). Wang et al (40) reported that cecropins could disrupt plasma membrane integrity of cancer cells when the concentration was $>60.9$ or $81.2 \mu \mathrm{g} / \mathrm{ml}$. Lee et al (41) observed that CopA3 mainly caused necrotic cell death of the gastric cancer cells. 
A
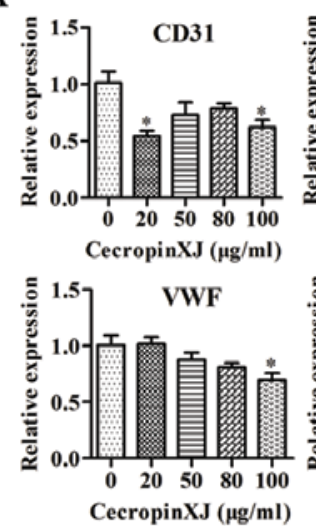
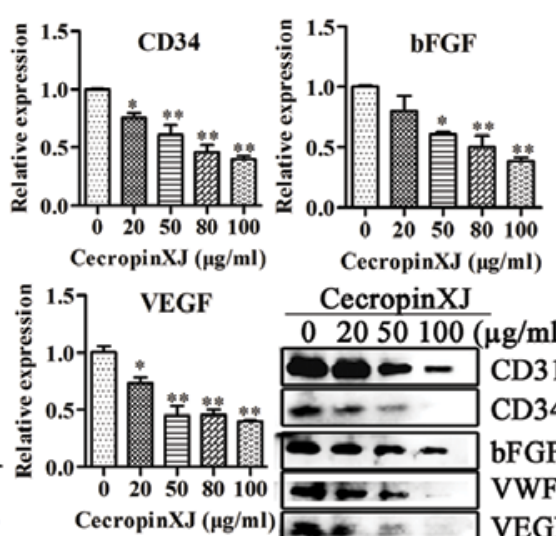

CecropinXJ

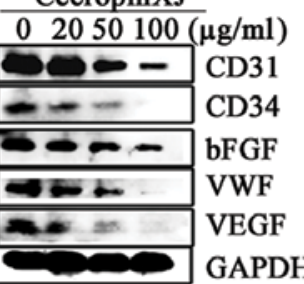

B
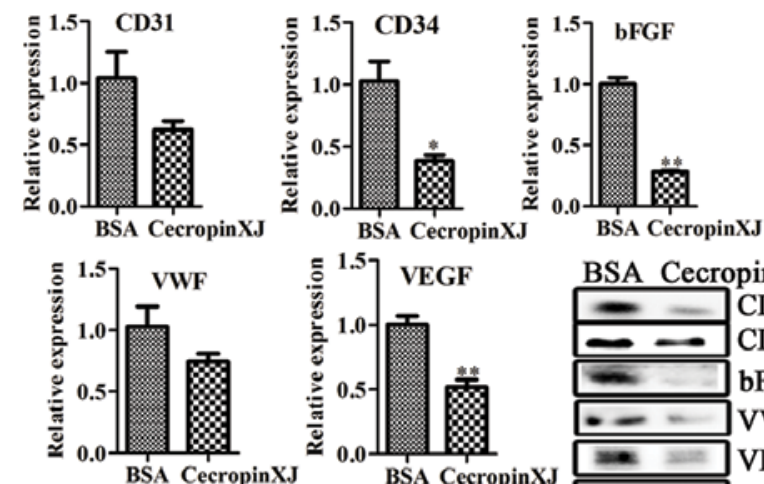

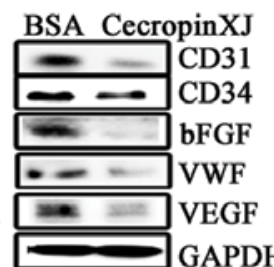

C

CD31

CD34

bFGF

VWF

VEGF

BSA

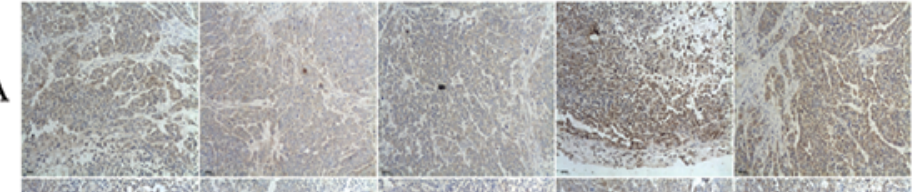

CecropinXJ

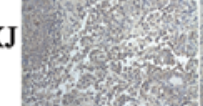

$\sin (x)$

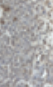

s.

Figure 7. Effects of cecropinXJ on the angiogenesis of BGC823 cells in vitro and in vivo. BGC823 cells were treated with various concentrations of cecropinXJ $(0,20,50,80$ and $100 \mu \mathrm{g} / \mathrm{ml})$ for $24 \mathrm{~h}$ and tumors were treated with cecropinXJ and BSA. (A) The expression of CD31, CD34, bFGF, VEGF and VWF in BGC823 cells were analyzed by qRT-PCR and western blot analysis. (B and C) qRT-PCR, western blot analysis and immunohistochemical staning were used to detection the expression of CD31, CD34, bFGF, VEGF and VWF in tumors.

However, in the present study, the LDH release of BGC823 cells was not increased after $80 \mu \mathrm{g} / \mathrm{ml}$ cecropinXJ treatment, and cecropinXJ mainly induced apoptosis of BGC823 cells. Consistent with our results, cecropin of Musca domestica induced DNA fragmentation to induce apoptosis (6). Therefore, cecropins may inhibit tumor cells through different mechanisms via inducing necrosis or apoptosis.

Cerón et al (26) reported that cecropin A was able to induce apoptosis in HL-60 cells through the production of ROS but independent of caspase activation. Huang et al (42) showed that pardxin, an antimicrobial peptide was first isolated from secretions of the Red Sea Moses sole, exerted antitumor effects on human fibrosarcoma HT-1080 cells by increasing intracellular ROS and activating caspase-3/7 activities. Our results showed that cecropinXJ increased ROS level and activated caspase-3/8/9 activity in BGC823 cells. Using caspase inhibitors, we further found that caspase-3/9 were involved in the induced apoptosis, but caspase- 8 had no effect.

Bcl-2 family proteins including anti-apoptotic (Bcl-2 and $\mathrm{Bcl}-\mathrm{xL}$ ) and pro-apoptotic members (Bax and Bad) play critical roles in the regulation of mitochondrial-mediated apoptosis or cell survival (43). Bcl-2 protein can bind to the outer membrane of the mitochondrion and prevent apoptosis, while Bax is responsible for permeabilizing the membrane $(44,45)$. It has been reported that melittin could decrease the expression of $\mathrm{Bcl}-2$ and induce the translocation of Bax to the mitochondria with the release of cytochrome $c$ into the cytosol, suggesting that mitochondria are involved in melittin-induced apop- tosis (46). In the present study, cecropinXJ treatment increased the release of cytochrome $c$ into the cytoplasm, decreased mitochondria $\Delta \psi_{\mathrm{m}}$, upregulated the expression of Bax and downregulated the expression of $\mathrm{Bcl}-2$ in vitro, suggesting that cecropinXJ triggered mitochondrion-dependent apoptosis. We further found that cecropinXJ inhibited growth of gastric cancer in mice and induced cancer cell apoptosis in tumors. Consistent with the in vitro results, cecropinXJ treatment could upregulate the expression of Bax and downregulate the expression of Bcl-2. Hence, cecropinXJ were able to induce the BGC823 cells apoptosis both in vitro and in vivo.

Angiogenesis is the formation of new blood vessels by the sprouting of endothelial cells from pre-existing vessels (47) and is essential for tumor growth and metastasis (48). It has been reported that suppression of angiogenesis might be an effective therapeutic approach against gastric cancer (49). A number of growth factors related to tumor angiogenesis have been identified which includes bFGF (50), VWF (51) and members of VEGF family (52). We found the expression of the CD31, CD34, VEGF, bFGF and VWF gene in BGC823 cells and BGC823-xenograft tumors was significantly decreased by cecropinXJ treatment, suggesting that cecropinXJ might inhibit tumor angiogenesis in vivo.

In summary, our results showed that cecropinXJ inhibits the growth of human BGC823 cells in vitro and in vivo through inducing apoptosis and preventing tumor angiogenesis. These results suggested that cecropinXJ has potential as a novel antitumor therapeutic strategy for the treatment of gastric cancer. 


\section{Acknowledgements}

We thank Professor Youyong Lv for providing the gastric cancer BGC823 cells and normal gastric epithelial GES-1 cells. The present study was supported by a grant from the High-Tech Research and Development Program of Xinjiang (no. 201110101).

\section{References}

1. Jemal A, Bray F, Center MM, Ferlay J, Ward E and Forman D: Global cancer statistics. CA Cancer J Clin 61: 69-90, 2011.

2. Nagini S: Carcinoma of the stomach: a review of epidemiology, pathogenesis, molecular genetics and chemoprevention. World J Gastrointest Oncol 4: 156-169, 2012.

3. Zasloff M: Antimicrobial peptides of multicellular organisms. Nature 415: 389-395, 2002.

4. Papo $\mathrm{N}$ and Shai Y: Host defense peptides as new weapons in cancer treatment. Cell Mol Life Sci 62: 784-790, 2005.

5. Paredes-Gamero EJ, Martins MN, Cappabianco FA, Ide JS and Miranda A: Characterization of dual effects induced by antimicrobial peptides: regulated cell death or membrane disruption. Biochim Biophys Acta 1820: 1062-1072, 2012.

6. Jin X, Mei H, Li X, Ma Y, Zeng A, Wang Y, Lu X, Chu F, Wu Q and Zhu J: Apoptosis-inducing activity of the antimicrobial peptide cecropin of Musca domestica in human hepatocellular carcinoma cell line BEL-7402 and the possible mechanism. Acta Biochim Biophys Sin 42: 259-265, 2010.

7. Wang C, Zhou Y, Li S, Li HB, Tian LL, Wang H and Shang DJ: Anticancer mechanisms of temporin-1CEa, an amphipathic $\alpha$-helical antimicrobial peptide, in Bcap-37 human breast cancer cells. Life Sci 92: 1004-1014, 2013.

8. Risso A, Braidot E, Sordan MC, Vianello A, Macrì F, Skerlavaj B, Zanetti M, Gennaro R and Bernardi P: BMAP-28, an antibiotic peptide of innate immunity, induces cell death through opening of the mitochondrial permeability transition pore. Mol Cell Biol 22: 1926-1935, 2002.

9. Sun KW, Ma YY, Guan TP, Xia YJ, Shao CM, Chen LG, Ren YJ, Yao HB, Yang Q and He XJ: Oridonin induces apoptosis in gastric cancer through Apaf-1, cytochrome c and caspase-3 signaling pathway. World J Gastroenterol 18: 7166-7174, 2012.

10. Furlong SJ, Mader JS and Hoskin DW: Bovine lactoferricin induces caspase-independent apoptosis in human B-lymphoma cells and extends the survival of immune-deficient mice bearing B-lymphoma xenografts. Exp Mol Pathol 88: 371-375, 2010.

11. Chen YL, Li JH, Yu CY, Lin CJ, Chiu PH, Chen PW, Lin CC and Chen WJ: Novel cationic antimicrobial peptide GW-H1 induced caspase-dependent apoptosis of hepatocellular carcinoma cell lines. Peptides 36: 257-265, 2012.

12. Huh JE, Kang JW, Nam D, Baek YH, Choi DY, Park DS and Lee JD: Melittin suppresses VEGF-A-induced tumor growth by blocking VEGFR-2 and the COX-2-mediated MAPK signaling pathway. J Nat Prod 75: 1922-1929, 2012.

13. Wang C, Chen T, Zhang N, Yang M, Li B, Lü X, Cao X and Ling C: Melittin, a major component of bee venom, sensitizes human hepatocellular carcinoma cells to tumor necrosis factorrelated apoptosis-inducing ligand (TRAIL)-induced apoptosis by activating CaMKII-TAK1-JNK/p38 and inhibiting IkappaBalpha kinase-NFkappaB. J Biol Chem 284: 3804-3813, 2009.

14. Xu XX, Jiang HR, Li HB, Zhang TN, Zhou Q and Liu N: Apoptosis of stomach cancer cell SGC-7901 and regulation of Akt signaling way induced by bovine lactoferrin. J Dairy Sci 93: 2344-2350, 2010.

15. Jeong YJ, Choi Y, Shin JM, et al: Melittin suppresses EGF-induced cell motility and invasion by inhibiting PI3K/Akt/ mTOR signaling pathway in breast cancer cells. Food Chem Toxicol 68: 218-225, 2014.

16. Fan Q, Hu Y, Pang H, Sun J, Wang Z and Li J: Melittin protein inhibits the proliferation of MG63 cells by activating inositolrequiring protein-1 $\alpha$ and X-box binding protein 1-mediated apoptosis. Mol Med Rep 9: 1365-1370, 2014.

17. Ting CH, Huang HN, Huang TC, Wu CJ and Chen JY: The mechanisms by which pardaxin, a natural cationic antimicrobial peptide, targets the endoplasmic reticulum and induces c-FOS. Biomaterials 35: 3627-3640, 2014.

18. Song CC, Lu X, Cheng BB, DU J, Li B and Ling CQ: Effects of melittin on growth and angiogenesis of human hepatocellular carcinoma BEL-7402 cell xenografts in nude mice. Ai Zheng 26: 1315-1322, 2007 (In Chinese).
19. Li J, Zhang F and Ma Z: Prokaryotic expression of cecropin gene isolated from the silk worm Bombyx mori Xinjiang race and antibacterial activity of fusion cecropin. Acta Entomol Sin 47: 407-411, 2004 (In Chinese).

20. Liu Z, Zhang F, Cai L, Zhao G and Wang B: Studies on the properties of cecropin-XJ expressed in yeast from Xinjiang silkworm. Wei Sheng Wu Xue Bao 43: 635-641, 2003 (In Chinese).

21. Wu Y, Xia L and Zhang F: Inhibition of CecropinXJ on proliferation of human gastric cancer AGS cells. Chinese J Cell Biol 36: 1355-1361, 2014 (In Chinese).

22. Xia L, Zhang F, Liu Z, Ma J and Yang J: Expression and characterization of cecropinXJ, a bioactive antimicrobial peptide from Bombyx mori (Bombycidae, Lepidoptera) in Escherichia coli. Exp Ther Med 5: 1745-1751, 2013.

23. Xia L, Liu Z, Ma J, Sun S, Yang J and Zhang F: Expression, purification and characterization of cecropin antibacterial peptide from Bombyx mori in Saccharomyces cerevisiae. Protein Expr Purif 90: 47-54, 2013.

24. Shai Y: Mechanism of the binding, insertion and destabilization of phospholipid bilayer membranes by alpha-helical antimicrobial and cell non-selective membrane-lytic peptides. Biochim Biophys Acta 1462: 55-70, 1999.

25. Mahassni SH and Al-Reemi RM: Apoptosis and necrosis of human breast cancer cells by an aqueous extract of garden cress (Lepidium sativum) seeds. Saudi J Biol Sci 20: 131-139, 2013.

26. Cerón JM, Contreras-Moreno J,Puertollano E, de Cienfuegos GÁ, Puertollano MA and de Pablo MA: The antimicrobial peptide cecropin A induces caspase-independent cell death in human promyelocytic leukemia cells. Peptides 31: 1494-1503, 2010.

27. Jeong JC, Jang SW, Kim TH, Kwon CH and Kim YK: Mulberry fruit (Moris fructus) extracts induce human glioma cell death in vitro through ROS-dependent mitochondrial pathway and inhibits glioma tumor growth in vivo. Nutr Cancer 62: 402-412, 2010.

28. She EX and Hao Z: A novel piperazine derivative potently induces caspase-dependent apoptosis of cancer cells via inhibition of multiple cancer signaling pathways. Am J Transl Res 5: 622-633, 2013.

29. Bao R, Shu Y, Wu X, et al: Oridonin induces apoptosis and cell cycle arrest of gallbladder cancer cells via the mitochondrial pathway. BMC Cancer 14: 217, 2014.

30. Folkman $\mathrm{J}$ : What is the evidence that tumors are angiogenesis dependent? J Natl Cancer Inst 82: 4-6, 1990.

31. Orditura M, Galizia G, Sforza V, et al: Treatment of gastric cancer. World J Gastroenterol 20: 1635-1649, 2014.

32. Garnier-Suillerot A, Marbeuf-Gueye C, Salerno M, Loetchutinat C, Fokt I, Krawczyk M, Kowalczyk T and Priebe W: Analysis of drug transport kinetics in multidrug-resistant cells: implications for drug action. Curr Med Chem 8: 51-64, 2001.

33. Moore AJ, Devine DA and Bibby MC: Preliminary experimental anticancer activity of cecropins. Pept Res 7: 265-269, 1994.

34. Suttmann H, Retz M, Paulsen F, Harder J, Zwergel U, Kamradt J, Wullich B, Unteregger G, Stöckle M and Lehmann J: Antimicrobial peptides of the Cecropin-family show potent antitumor activity against bladder cancer cells. BMC Urol 8: 5, 2008.

35. Jin XB, Wang YJ, Liang LL, Pu QH, Shen J, Lu XM, Chu FJ and Zhu JY: Cecropin suppresses human hepatocellular carcinoma BEL-7402 cell growth and survival in vivo without side-toxicity. Asian Pac J Cancer Prev 15: 5433-5436, 2014.

36. Boman HG: Antibacterial peptides: basic facts and emerging concepts. J Intern Med 254: 197-215, 2003.

37. Zhang WM, Lai ZS, He MR, Xu G, Huang W and Zhou DY: Effects of the antibacterial peptide cecropins from Chinese oak silkworm, antheraea pernyi on 1, 2-dimethylhydrazine-induced colon carcinogenesis in rats. Di Yi Jun Yi Da Xue Xue Bao 23: 1066-1068, 2003 (In Chinese).

38. Hui L, Leung K and Chen HM: The combined effects of antibacterial peptide cecropin A and anti-cancer agents on leukemia cells. Anticancer Res 22: 2811-2816, 2002.

39. Harris F, Dennison SR, Singh J and Phoenix DA: On the selectivity and efficacy of defense peptides with respect to cancer cells. Med Res Rev 33: 190-234, 2013.

40. Wang C, Tian LL, Li S, Li HB, Zhou Y, Wang H, Yang QZ, Ma LJ and Shang DJ: Rapid cytotoxicity of antimicrobial peptide Tempoprin-1CEa in breast cancer cells through membrane destruction and intracellular calcium mechanism. PLoS One 8: e60462, 2013.

41. Lee JH, Kim IW, Kim SH, Yun EY, Nam SH, Ahn MY, Kang DC and Hwang JS: Anticancer activity of CopA3 dimer peptide in human gastric cancer cells. BMB Rep: Jul 22, 2014 (Epub ahead of print). 
42. Huang TC, Lee JF and Chen JY: Pardaxin, an antimicrobial peptide, triggers caspase-dependent and ROS-mediated apoptosis in HT-1080 cells. Mar Drugs 9: 1995-2009, 2011.

43. Tsujimoto Y: Bcl-2 family of proteins: life-or-death switch in mitochondria. Biosci Rep 22: 47-58, 2002.

44. Du L, Mei HF, Yin X and Xing YQ: Delayed growth of glioma by a polysaccharide from Aster tataricus involve upregulation of $\mathrm{Bax} / \mathrm{Bcl}-2$ ratio, activation of caspase-3/8/9, and downregulation of the Akt. Tumour Biol 35: 1819-1825, 2014.

45. Das A, Banik NL, Patel SJ and Ray SK: Dexamethasone protected human glioblastoma U87MG cells from temozolomide induced apoptosis by maintaining Bax:Bcl-2 ratio and preventing proteolytic activities. Mol Cancer 3: 36, 2004.

46. Gajski G and Garaj-Vrhovac V: Melittin: a lytic peptide with anticancer properties. Environ Toxicol Pharmacol 36: 697-705, 2013.

47. Emmett MS, Dewing D and Pritchard-Jones RO: Angiogenesis and melanoma: from basic science to clinical trials. Am J Cancer Res 1: 852-868, 2011.
48. Folkman J: Role of angiogenesis in tumor growth and metastasis Semin Oncol 29: 15-18, 2002.

49. Javle M, Smyth EC and Chau I: Ramucirumab: successfully targeting angiogenesis in gastric cancer. Clin Cancer Res 20: 5875-5881, 2014

50. Presta M,Dell'Era P, Mitola S, Moroni E, Ronca R and Rusnati M: Fibroblast growth factor/fibroblast growth factor receptor system in angiogenesis. Cytokine Growth Factor Rev 16: 159-178, 2005.

51. Starke RD, Ferraro F, Paschalaki KE, et al: Endothelial von Willebrand factor regulates angiogenesis. Blood 117: 1071-1080, 2011.

52. Aoyagi K, Kouhuji K, Kizaki J, Isobe T, Hashimoto K and Shirouzu K: Molecular targeting to treat gastric cancer. World J Gastroenterol 20: 13741-13755, 2014. 